\title{
تأثير نوع المنظف الصناعي على الخواص الوظيفية لبعض الأقمشة الصوفية المخلوطة"
}

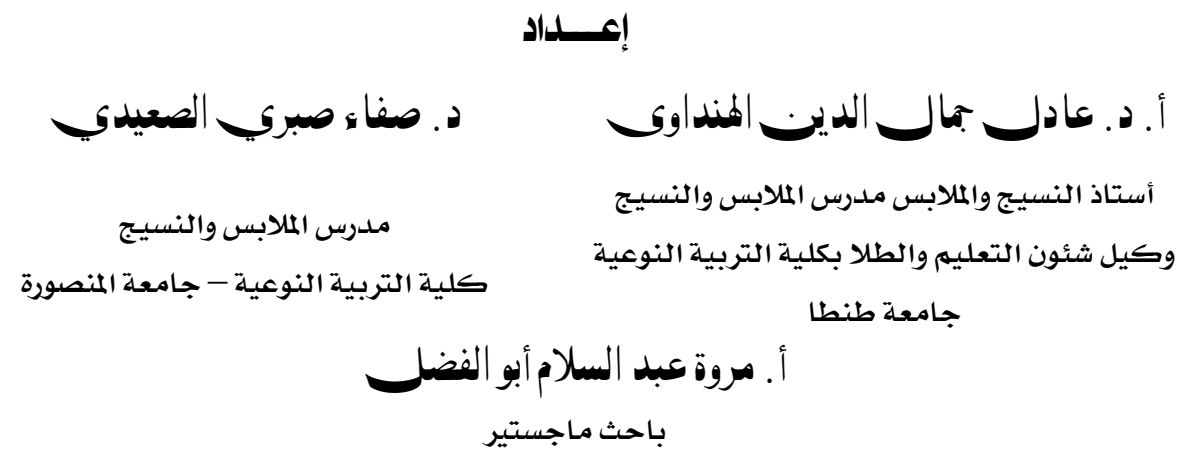

مجلة بحوث التربية النوعية - جامعة المنصورة

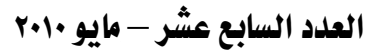




\section{تأثير نوع المنظف الصناعي على الخواص الوظيفية لبعض الأقمشة الصوفية المخلوطة"}

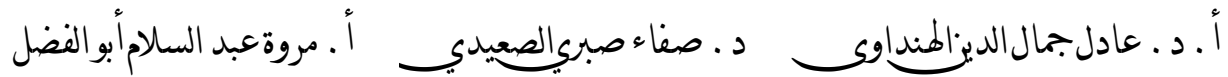

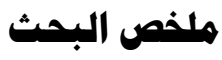

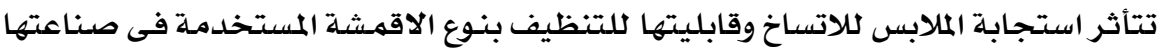

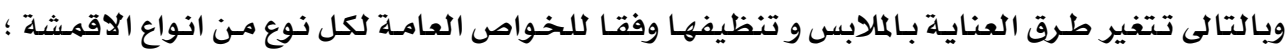

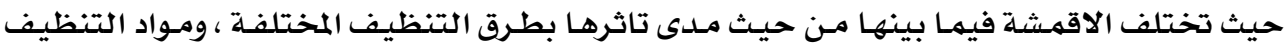

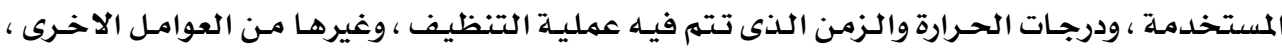

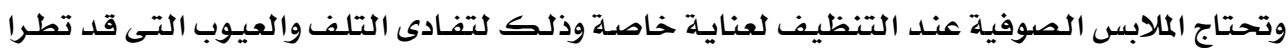
على الاقمشة اثناء عملية التنظيف .

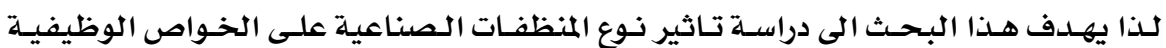

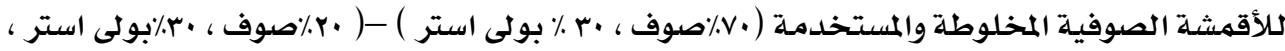

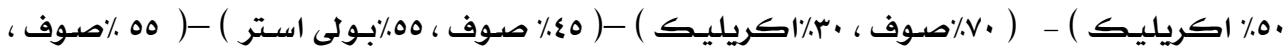

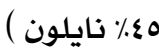

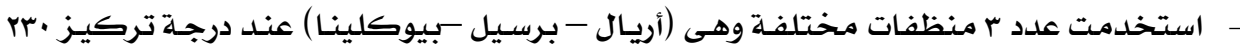

$$
\text { مللى لتر }
$$

- - درجة حرارة الغسيل المستخدمة فى غسيل الاقمشة 40 مئوية لكل العينات - - عدد مرات الغسيل : 0 غسلات متتالية

- استخدمت طريقة الغسيل الاوتوماتيك وبرنامج غسيل ثابت لاجراء تجارب البحث وهو برنامج

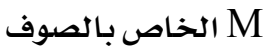

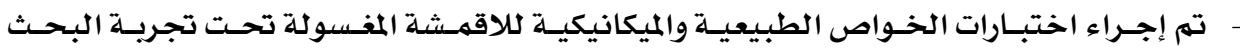

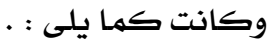

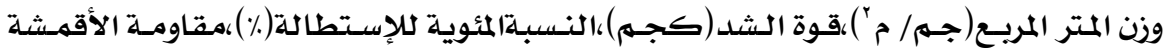

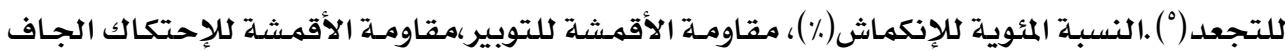




$$
\text { وكانت النتائج كما يلى : }
$$

حقت الأقمشة المغسولة بالمنظف بيوكلينا افضل المواصفات يليها المنظفان بيرسيل واريال

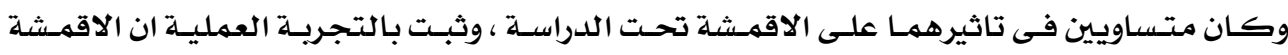

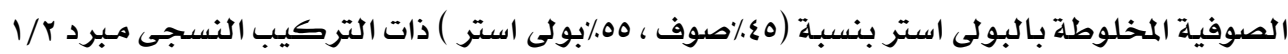

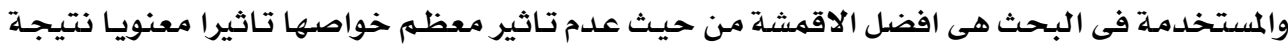
استخدام المنظفات الصناعية المستخدمة في البحل البحثث. 


\section{ABSTRACT}

Woolen clothes need aspecial care in order to avoid damage and defects which occur on clothes during the process of cleaning .

So the aim of this research is to find the effects of some detergents on the physical and mechanical properties of the washed fabrics.

\section{Following fabrics are used}

(70\%wool - 30\%polyester ). $(20 \%$ wool- $30 \%$ polyester- $50 \%$ poly acrylic)-(70\%wool- $30 \%$ poly acrylic)-(45\%wool- $55 \%$ polyester)(55\%wool-45\%nylon)

\section{Three different sorts of detergents are used}

(arial - persil-bio cleana)and concentration rate (230)ml.

-automatic laundry process was served

-Experiments for physical and mechanical fabric properties were

executed after washing as:-

1 -strength and elongation test.

2-weight of square meter test.

3-shrinkinge test.

4-wrinkle resistance test.

5-pilling test

6-friction test

7-handle test

following results were obtained detergents

fabrics washed with Bio cleana show the best properties compared with other detergents.

Persil and arial have some effect on the physical and mechanical properties of the washed fabrics.

Experiment proved that woolen fabrics blended polyster ( $40 \%$ wool$55 \%$ polyster)with the twill syructure from (2/1)show the best aspects. detergent

Compared with other fabrics. Which Cant be effect by using 


\section{تأثير نوع المنظف الصناعي على الخواص الوظيفية

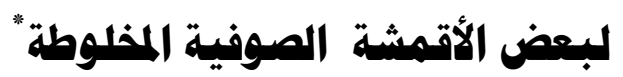

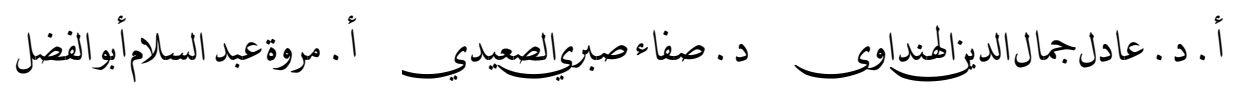

المقدهة

ا_خواص الصوف

يعتبر الصوف من أول الخامات التي استخدمت ِِّ صناعة الملابس وهو مـن أفضل الخامـات

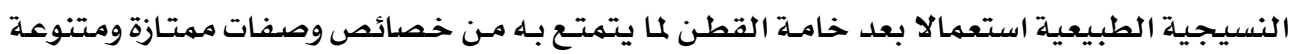

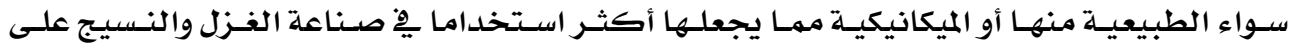

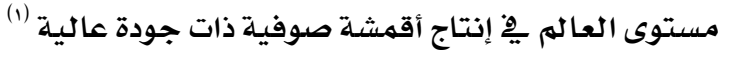

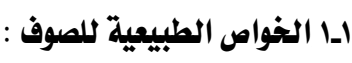

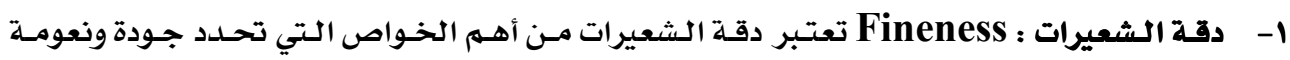

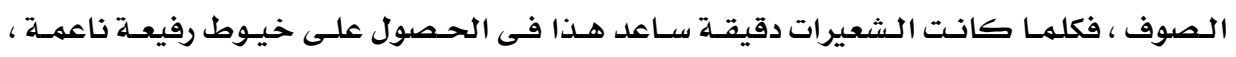

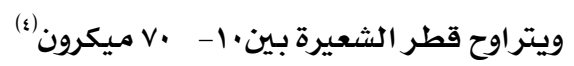

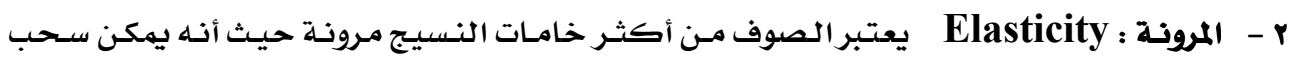

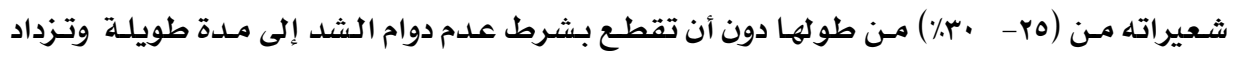

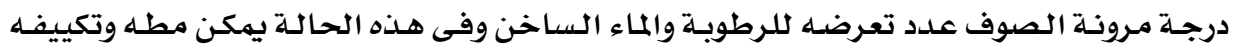

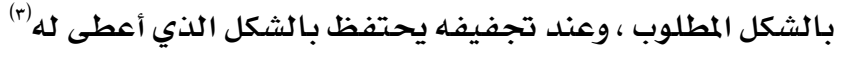

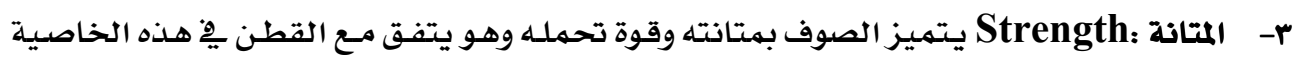

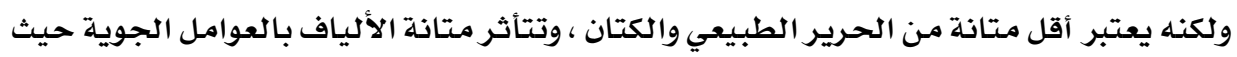

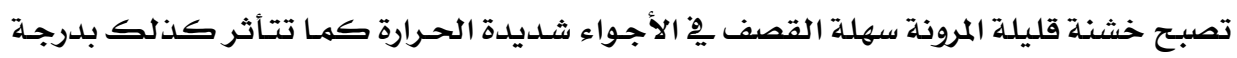

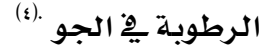

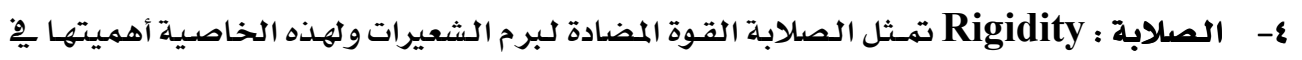

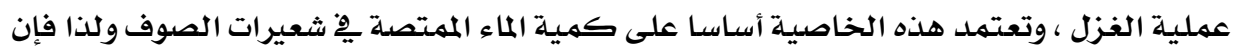

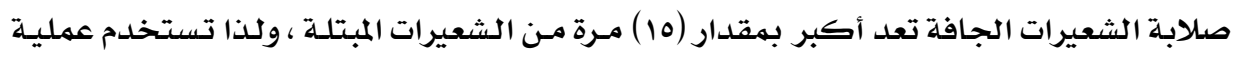

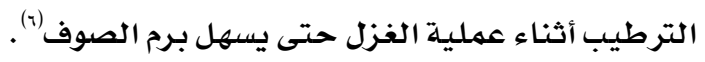




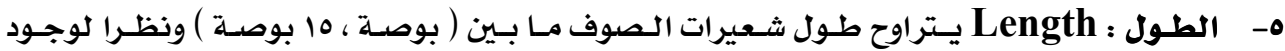

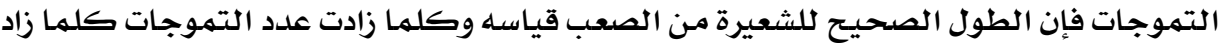

$$
\text { طول الشعيرة (ع). }
$$

T- امتصاص الرطوبة : Relative Humidit Hيستاز الصوف بسهولة امتصاصه للرطوبة وهى

خاصيلة مهمة عند الاستعمال يِّ المالابس الداخلية حيث يمتص كميات كبيرة من الرطوبة التي

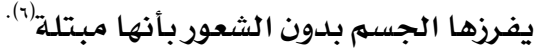

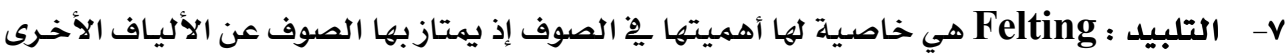

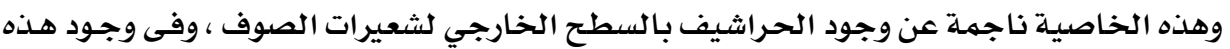

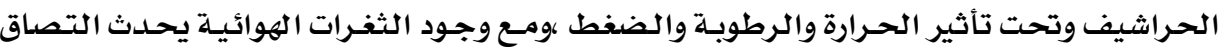

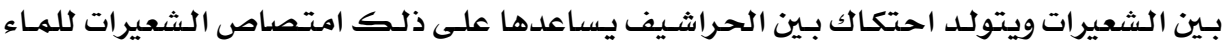

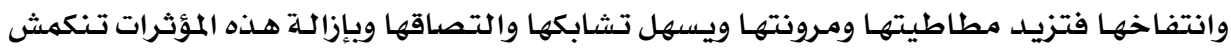

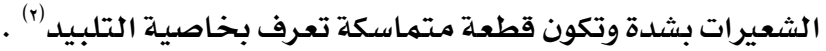

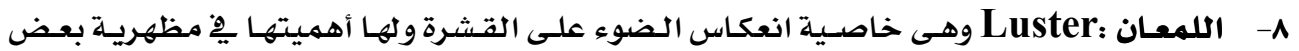

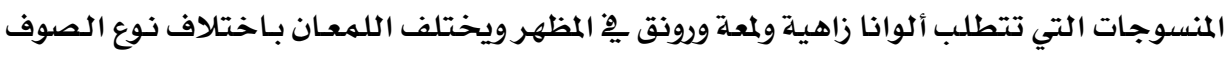

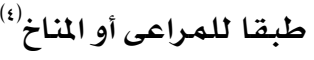

9- اللون : Colour يختلف لـون الصوف بـين الأبيض والسهنى والأسـود والبنى ، غير أن الأبيض

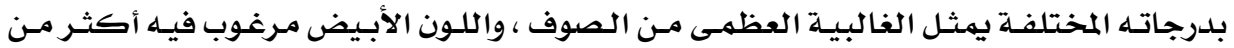

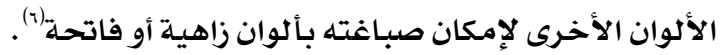

• - الاستطالة : Elongation لأليـاف الصوف قدرة على الإستطالة من (0ץ - هץ٪) من أطوالها

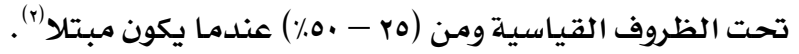

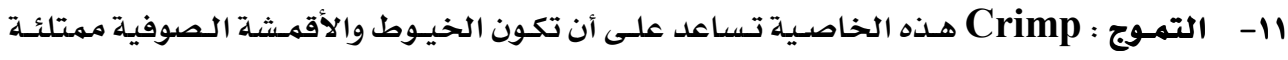

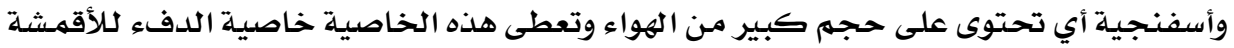
الصوفية لأن الهواء المحبوس داخل هذه الفراغات يعمل كعازل حسئ حراري قوى التأثير (r).

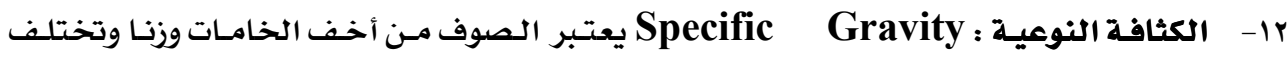

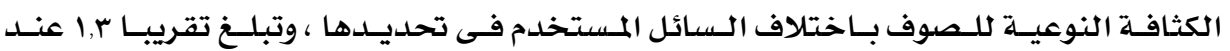

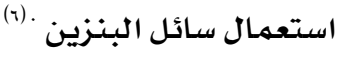

اـr الخواص الكهربائية للصوف :

الصوف موصل ردئ للكهرياء ولكن من السهل أن يحمل شـحنات كهريائيـة إستاتيكيه والتي

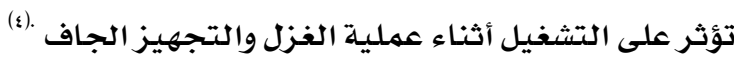


الصوف موصـل ردئ للحـرارة فهـو يحفظ الحـرارة المتولـدة مـن الجسـم أثنـاء الشتاء فيشعر

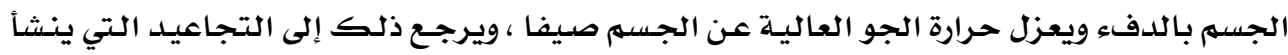

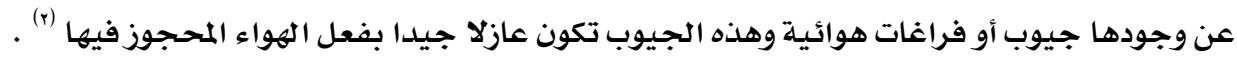

اــ الخواص الكيميائية للصوف :

ا- - تـأثير القلويـات : يـتأثر الـصـوف تـأثيرا واضـحا بالقلويـات فيتحلـل الـصوف ويـذوب باسـتخدام

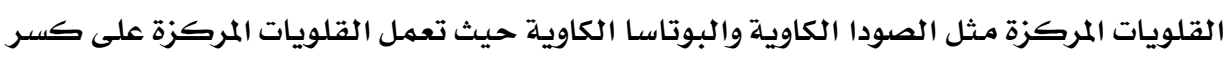

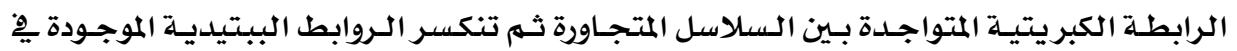

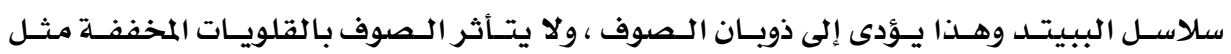

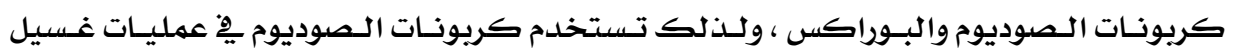

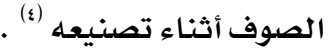

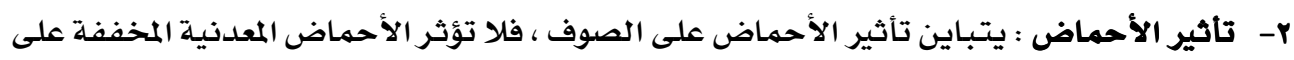

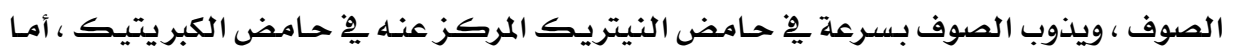

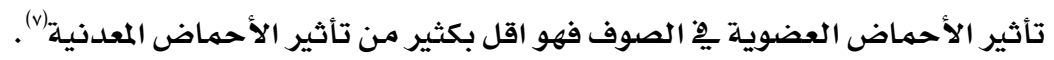

ץ- تأثير المواد المؤكسدة : تؤثر المواد المؤكسدة على الصوف يِ أثناء عمليـات التبييض ،وفى إزالة

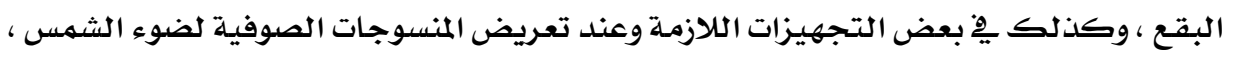

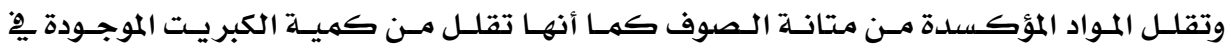

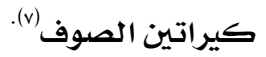

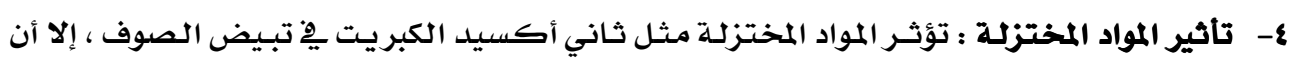

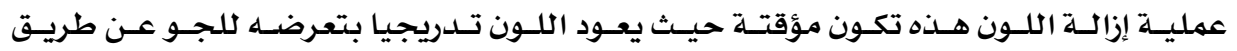

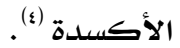

ه- تأثير الأملاح : لا يهتص الصوف بعض الأمـلاح بسهولة كملـح الطعام ( كلوريـ الصوديوم ) ،

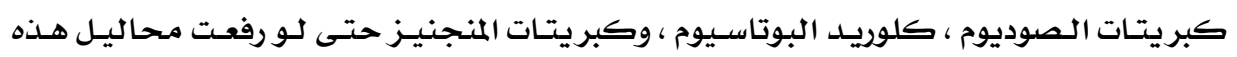

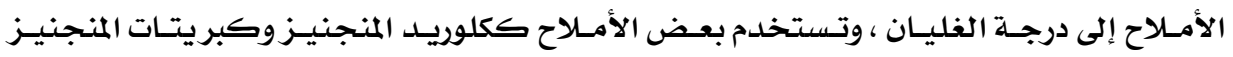

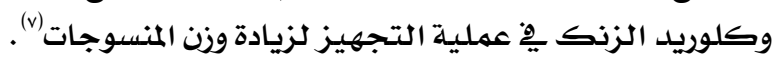

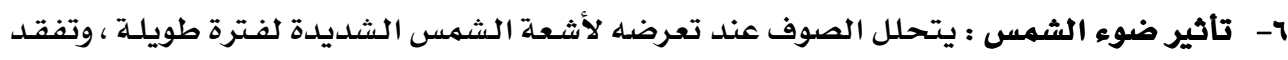

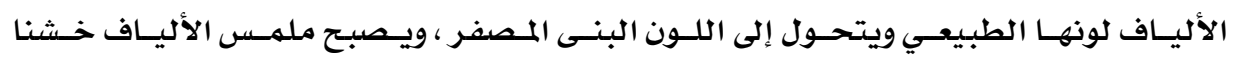
قليل المتانة (v) قلئاف لون

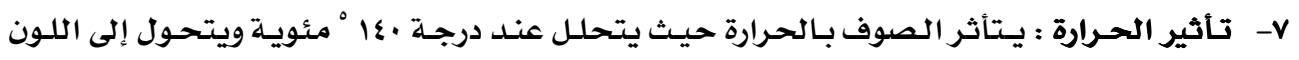

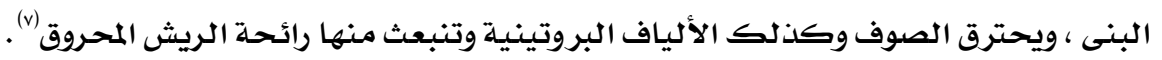




\section{ץـ بعض الخواص الوظيفية للأقمشة والعوامل التى تؤثر عليها}

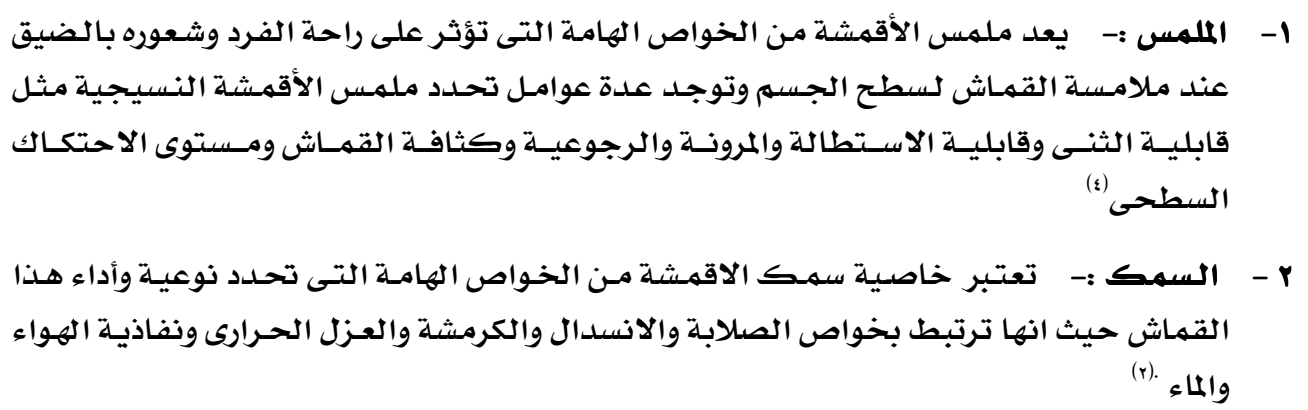

r- قوة الشد والاستطالة :- - يؤثر متوسط قطر الشعرة بشكل معنوى على قوة شـد القمـاش ،

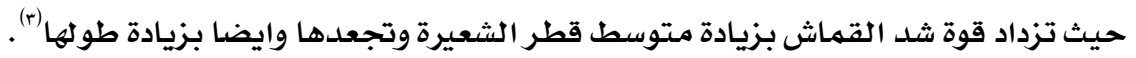
ع- مقاومة التجعد :- تعتبر مقاومة التجعد (wrinkle resistance) مـن الخـواص الهامـة التى

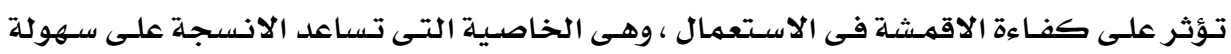

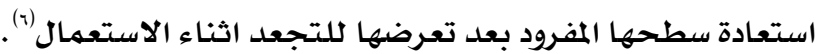

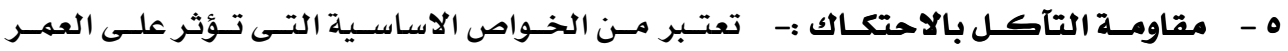

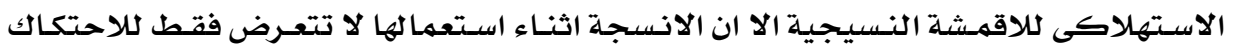

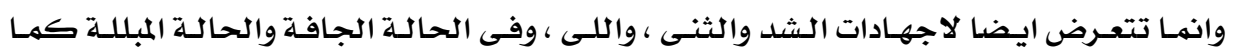

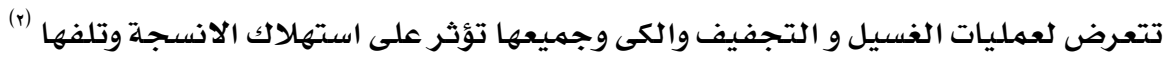
7 - بات الأبعاد :- يهتم المستهلك دائما بأن يحتفظ بالملابس التى يستعملها بمظهرها بحيث لا

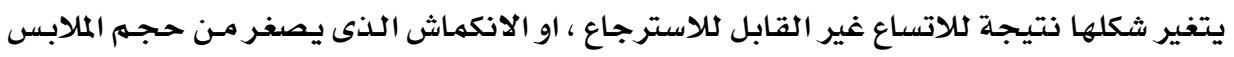

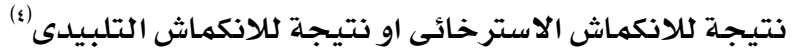
(Relaxation Shrinkage) - - الانكماش الاسترخائى )

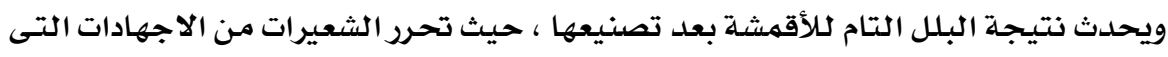

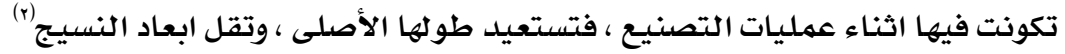
Fellting Shrainkage : بـ الانكماش التلبيدى عند غسل الاقهـة الصوفية يحـدث بها تغير فى الابعـاد ، فتفقد الملابس حجمها العـادى ،

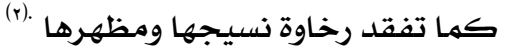




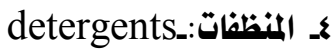
كـا تعريف المنظف وخواص المنظف الجيد :

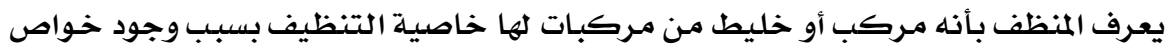

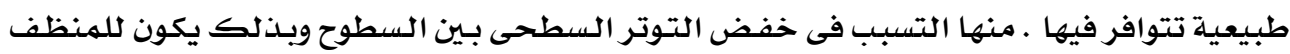

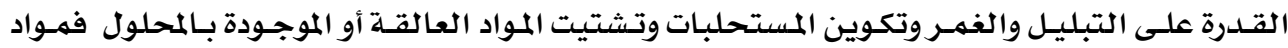

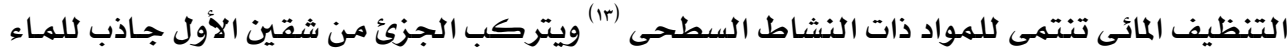

واخر طارد للماء وأن الصابون يتفق مـع المنظفات الصناعية فى الخاصيتين الاتيتين :-

$$
\text { ب- خفض التوتر السطحى للماء والسوائل بشدة . }
$$

ولكن المنظفات الصناعية تختلف عن الصابون في سهولة الدوبان فئل في الماء البـارد والساخن

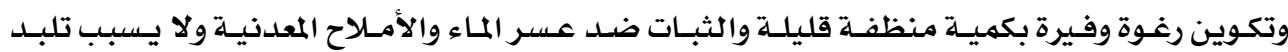

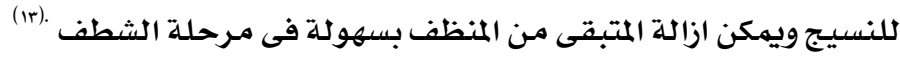

Sـــ المنظفات الصناعية Synthetic detergents

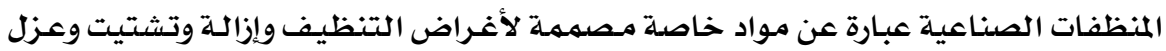

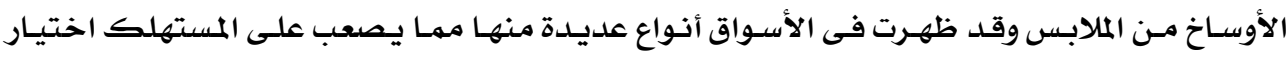
أفضلها للمحافظة على المنسوجات واعطاء أعلى كفاءة تنظيف باقل الأسعار وتوفير الأوفير الوقت والجهد (1)

\section{أنواع المنظفات الصناعية}

$$
\text { تنحصر أنواع المنظفات الصناعية تحت ثلاثة أقسام رئيسية وهى : }
$$

أ- النوع المتعادل : والذى لا يحتوى على أى اضـافات خارجية ويصلح لجميع الأغراض ويفضل

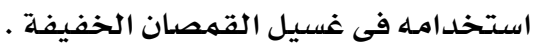

ب- نوع يحتوى على قليل مـن المادة القلويـة وهو يزيد مـن قدرة المنظف على إزالة الاتساخات

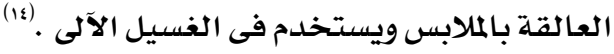

جـ- ــوع يعطى رغـوة وفيرة أكثر مـن الـصابون ويستخدم فى الغسالات العاديـة والغسيل كــ المنظف الصناعى ودور كل منها فى فاعلية المنظف:.

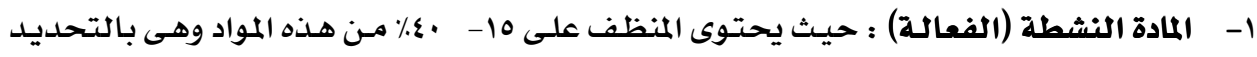

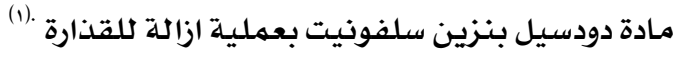


ب- مواد بناءة : عادة مـا تكون املاح الفوسفات مثل ثنائى الفوسفات وهى تعهـل على زيـادة فعاليـة

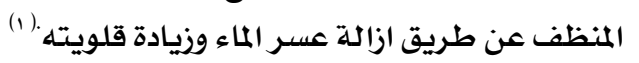

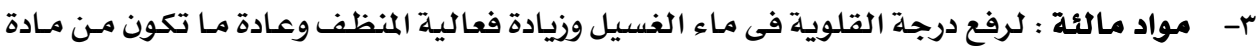

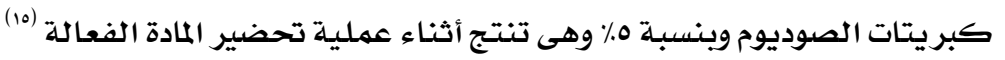

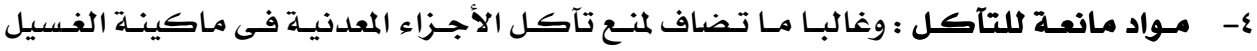

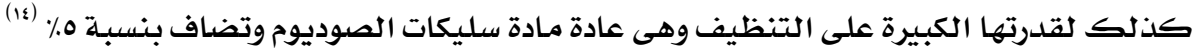

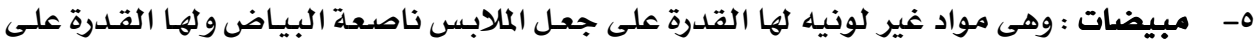

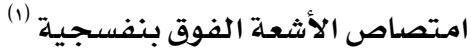

צ- مواد للتأثير النفسى : وهى تسـاعد على ثبـات الرغوة وتقلل مـن التـاثير الضار للمنظف على

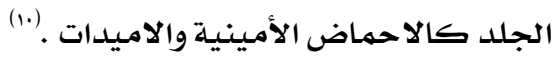

V- مواد معطره : وهى تضاف للهنظف للتغلب على رائحسة المواد الكيميائيـة المصنع منها وتعطى

رائحة محببـة للنفس معلده : (1)

\section{عـى ميكانيكية عمل المنظفات الصناعية :}

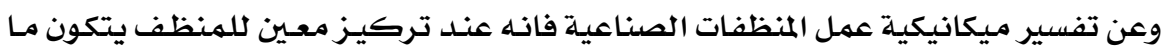

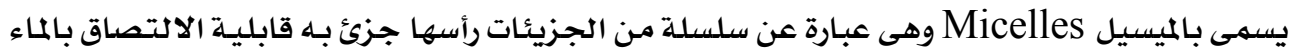

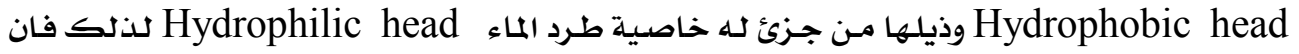

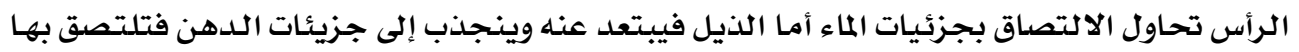

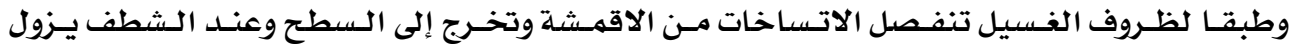

الميسيل وتتم عملية التنظيف (10) 


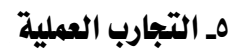

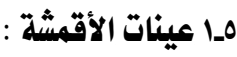

تم إنتاج عينات الأقمشة تحت البحث بشركة مصر للغزل والنسيج بالمواصفات التالية :

جدول (1) مواصفات الأقمشة المستخدمة تحت الدراسـة مجهز

\begin{tabular}{|c|c|c|c|c|c|}
\hline نسب الخلط & عددالحدفات/ البوصة & سمرة الخيط & عدد فتل البوصة & التركيب & رقهم العينـة \\
\hline 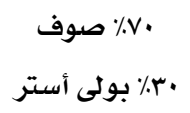 & or & بr/ץمترى & Tr & مبرد Y/r & 1 \\
\hline 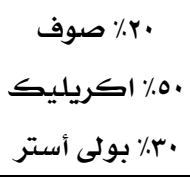 & $\varepsilon V$ & דr/Y مترى & Tr & مبرد Y Y r & $r$ \\
\hline 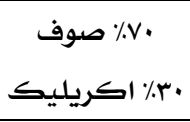 & $0 \varepsilon$ & ه§/r مترى & 70 & مبرد ץ/ & $r$ \\
\hline 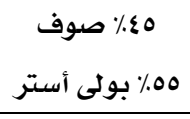 & $0 \Lambda$ & . Yمترى /0 & $v$. & مبرد Y/ & $\varepsilon$ \\
\hline 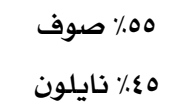 & r & rا/امترى & $\varepsilon \wedge$ & مبرد Y/Y & 0 \\
\hline
\end{tabular}

\section{إن الاختبارات التى تم إجراؤها على الأقشة تحت البحث :}

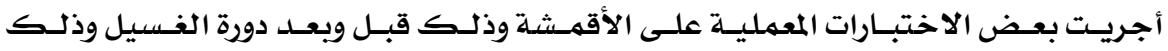

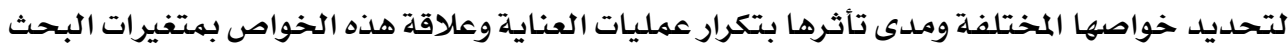

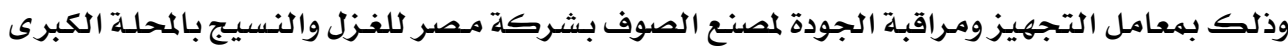

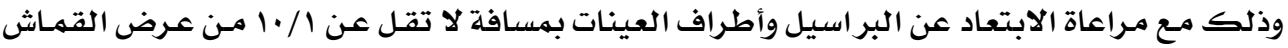

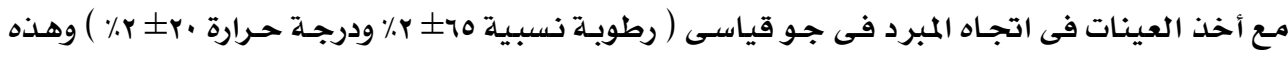

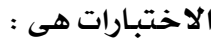

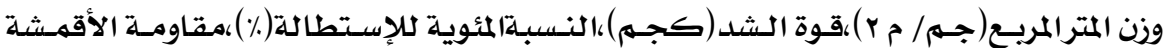

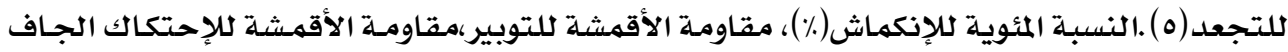


1_ا تأثير نوع مسحوق الفسيل على قوة شد القماش فى اتجاه السداء

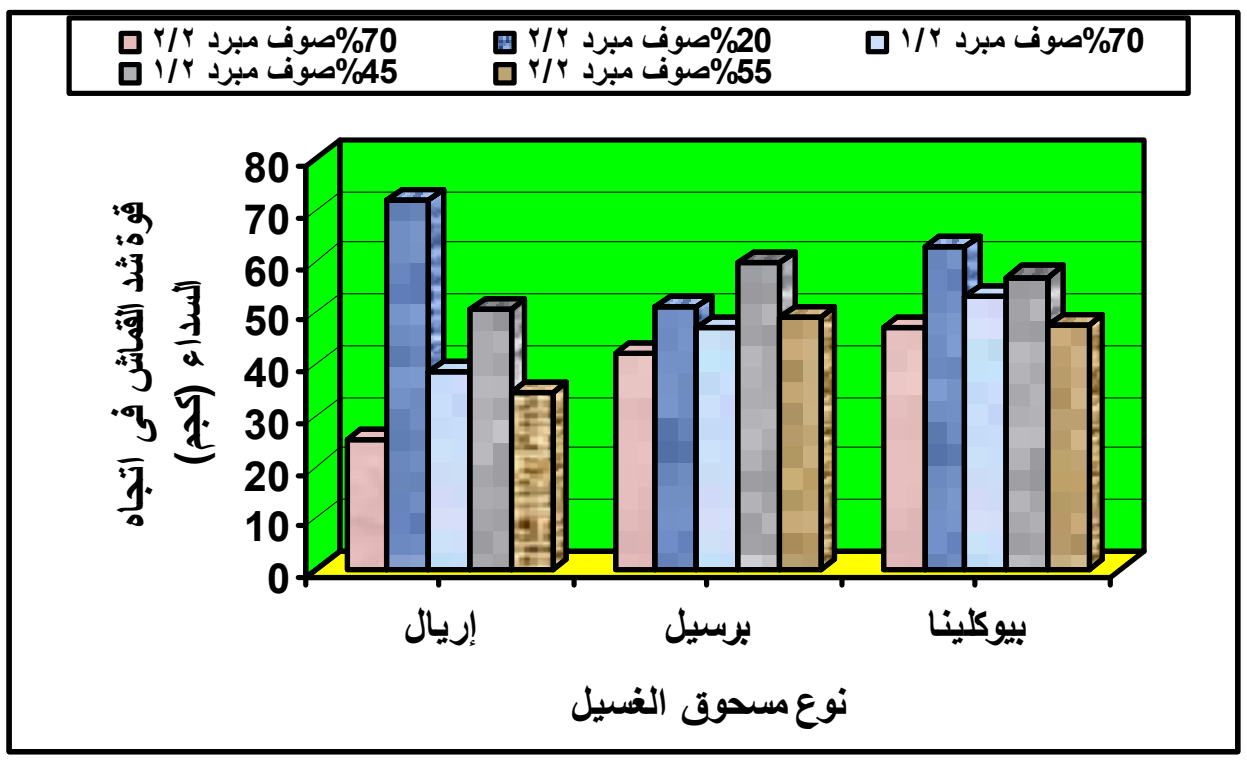

شكل( ) العلاقة بين نوع مسحوق الغسيل وقوة شد القماش فى اتجاه السداء للعينات المختلفة عند تركيز ·. بr مللى لتر جدول(r) : تحليل التباين لتأثير نوع مسحوق الغسيل على قوة شد القماث فى اتجاه السلداء للعينات المختلفة عند تركيز ·rr مللى لتر

\begin{tabular}{|c|c|c|c|c|c|c|}
\hline قالجدولية فيمة & مستوى المعنوية & قالمحسوبة ف & متوسط المربعات & درجات & مجمبوع المربعات & مصدر \\
\hline \multirow[t]{3}{*}{3.354131} & 0.001151 & 8.785848 & 5635.084 & 2 & 11270.17 & المجموعات \\
\hline & & & 641.382 & 27 & 17317.31 & المجموعات \\
\hline & & & & 29 & 28587.48 & المجموع \\
\hline
\end{tabular}

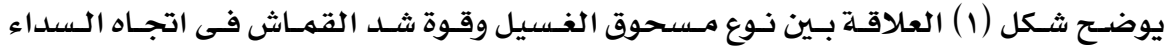

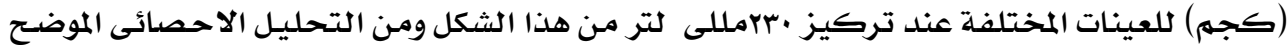

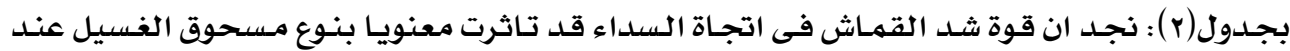

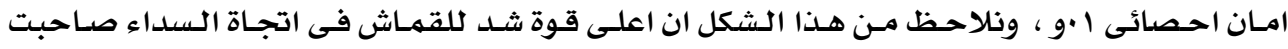




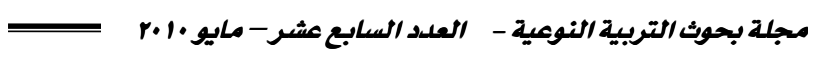

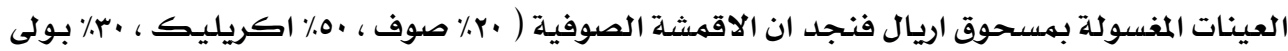

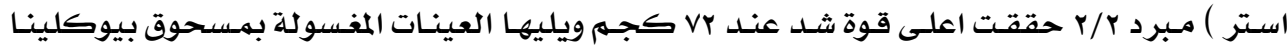

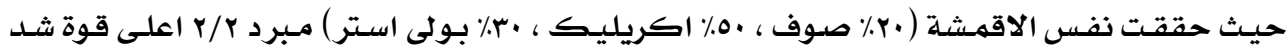

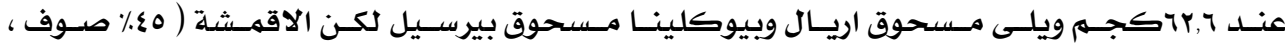

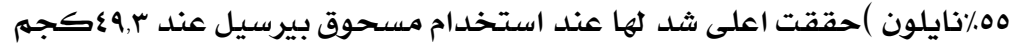

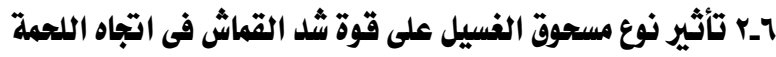

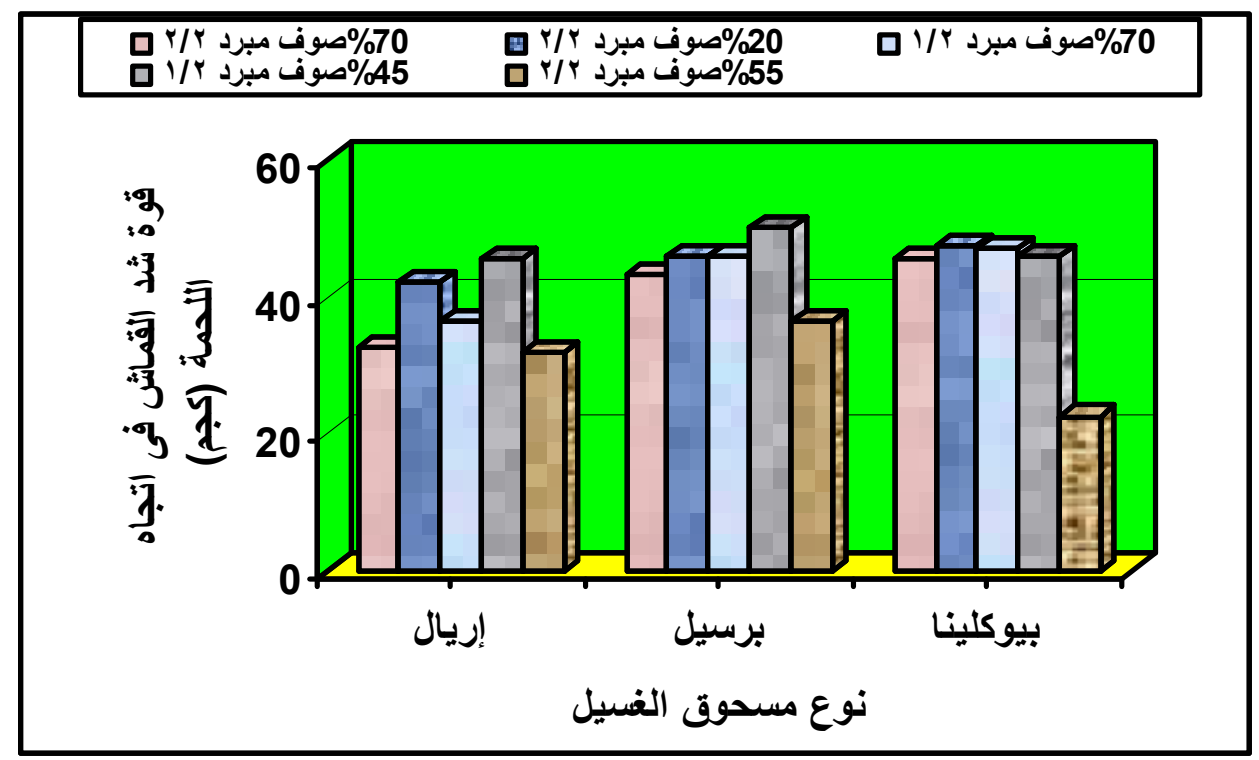

شكل (r) : العلاقة بين نوع مسحوق الغسيل وقوة شد القماش في اتجاه اللحمة للعينات المختلفة عند تركيز ·r ملكلى لتر

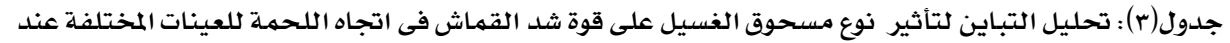
تركيز ·rr مللى لتر

\begin{tabular}{|c|c|c|c|c|c|c|}
\hline قبمة ف & مستوى & قيمة ف & متوسط & درجات & المربعات & مصدر التباين \\
\hline \multirow[t]{3}{*}{3.219938} & 0.027061 & 3.938441 & 162.6889 & 2 & 325.3778 & بين المجموعات \\
\hline & & & 41.30794 & 42 & 1734.933 & داخل المجموعات \\
\hline & & & & 44 & 2060.311 & المجموع \\
\hline
\end{tabular}

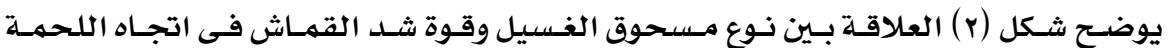

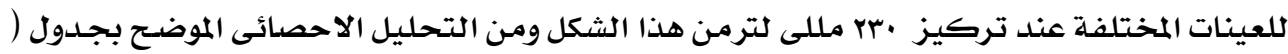

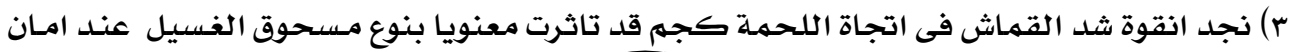




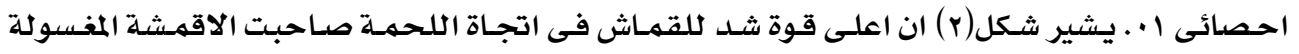

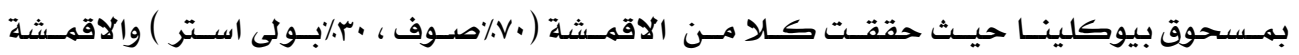

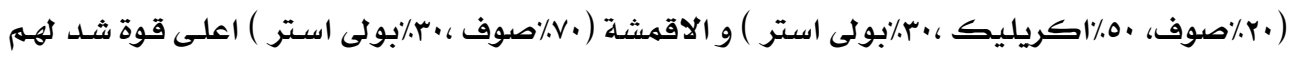

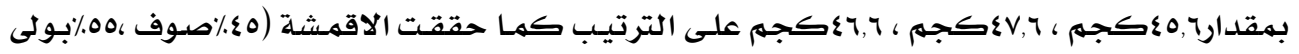

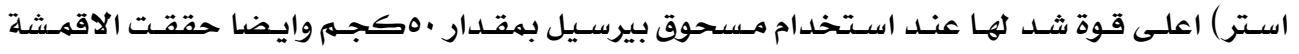

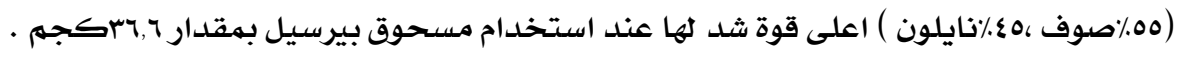

آب تأثير نوع مسحوق الفسيل على استطالة القماش فى اتجاه السداء

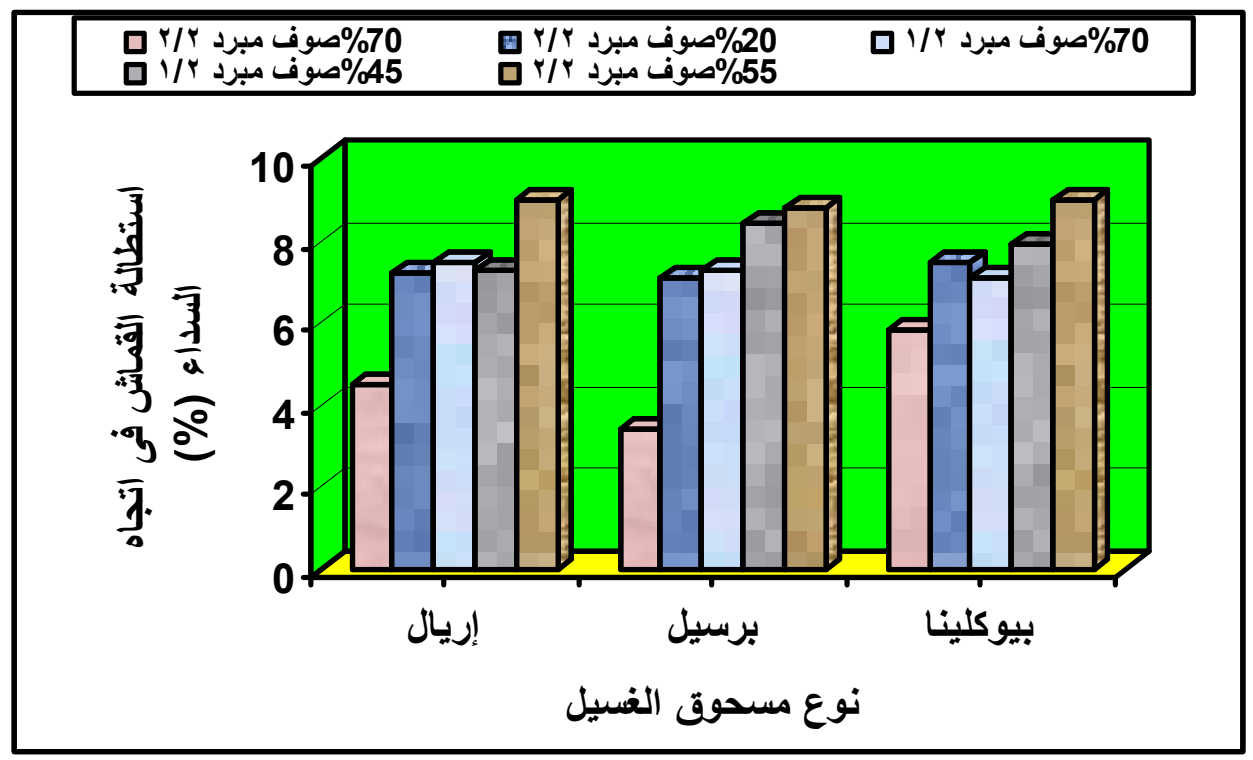

شكل(r) : العلاقة بين ذوع مسحوق الغسيل و استطالة القماث فى اتجاه السداء للعينات المختلفة عند

$$
\text { تركيز ·rr مللى لتر }
$$

جدول(ع) : تحليل التباين لتأثير نوع مسحوق الغسيل على استطالة القماث فى اتجاه السداء للعينات المختلفة عند تركيز ·rr مللى لتر

\begin{tabular}{|c|c|c|c|c|c|c|}
\hline قيمة ف & مستتوى المعنوية & قيمة ف & متوسط المربعات & درجـات & ملجهموع المربعات & مصدر التباين \\
\hline \multirow[t]{3}{*}{3.354131} & 0.795736 & 0.230433 & 0.585333 & 2 & 1.170667 & بين المجهموعات \\
\hline & & & 2.540148 & 27 & 68.584 & داخل المجهموعات \\
\hline & & & & 29 & 69.75467 & المجموع \\
\hline
\end{tabular}




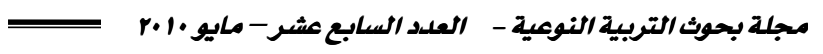

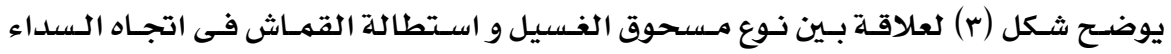

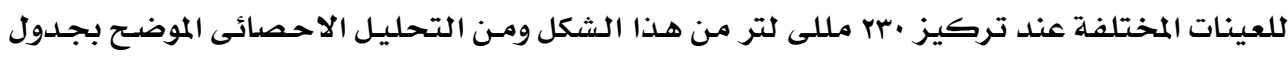

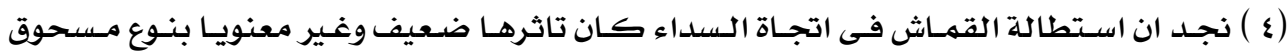
الغسيل .

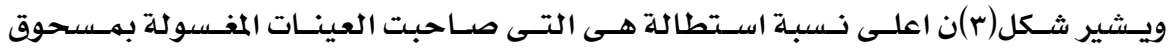

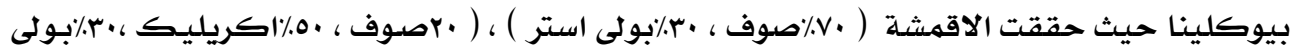

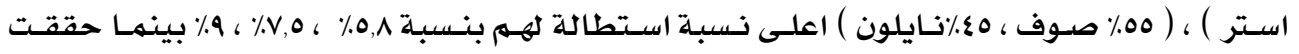

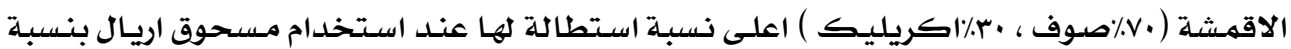

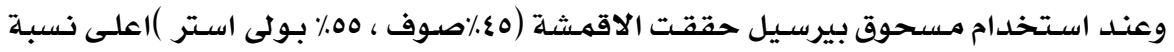

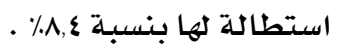

1ــ تأثير نوع مسحوق الفسيل على استطالة القماش فى اتجاه اللحمة

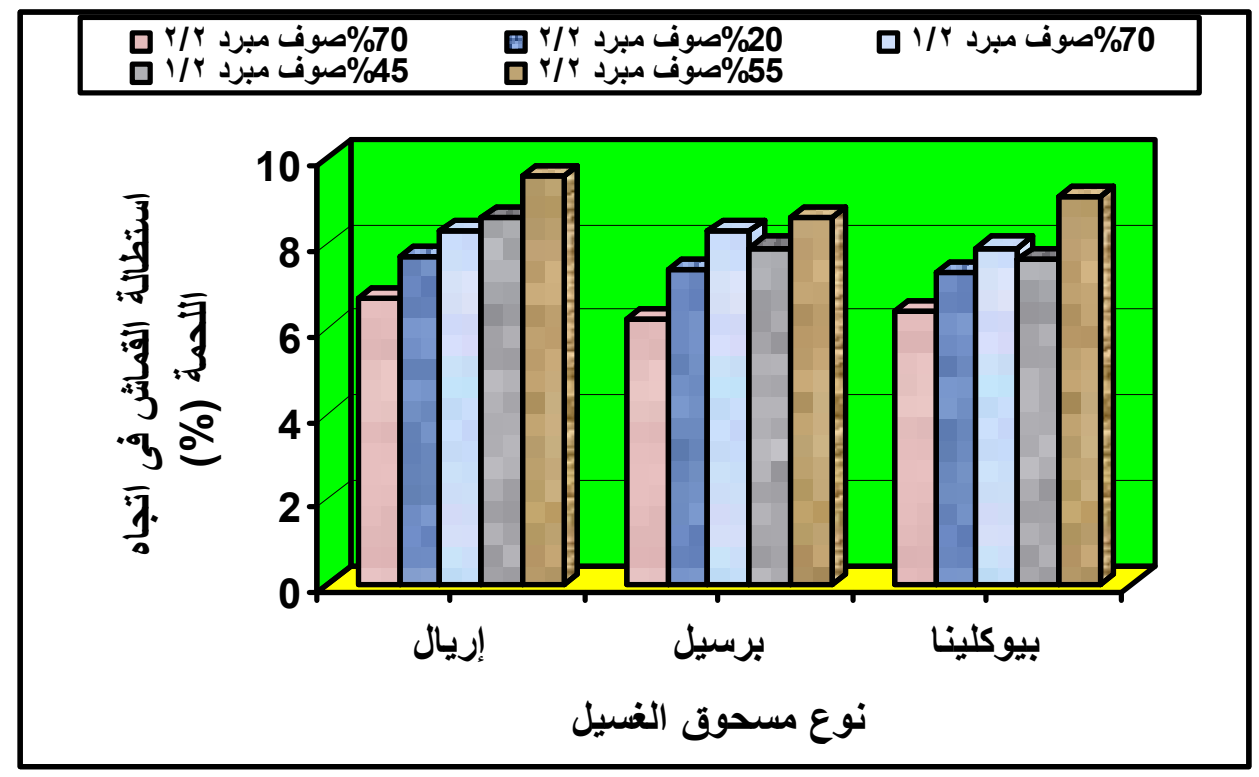

شكل(ع )العلاقة بين نوع مسحوق الغسيل و استطالة القماش فى اتجاه اللحمة للعينات المختلفة عند تركيز ·rr مللى لتر 
جدول(ه) : تحليل التباين لتأثير نوع مسحوق الغسيل على استطالة القماش فى اتجاه اللحمة للعينات المختلفة

عند تركيز ·rr مللى لتر

\begin{tabular}{|c|c|c|c|c|c|c|}
\hline قيمسة ف & مستوى المعنوية & قلمسمسة في & متوسط المربعات & الحرجـات & مجمهوع & مصدر التبـاين \\
\hline \multirow[t]{3}{*}{3.354131} & 0.181885 & 1.816645 & 26.572 & 2 & 53.144 & بين المجموعات \\
\hline & & & 14.62696 & 27 & 394.928 & داخل المجموعات \\
\hline & & & & 29 & 448.072 & المجموع \\
\hline
\end{tabular}

يوضـح شـكل (ع ) العلاقـة بـين نـوع مستحوق الغسيل و اسـتطالة القمـاش فى اتجـاه اللحمــة

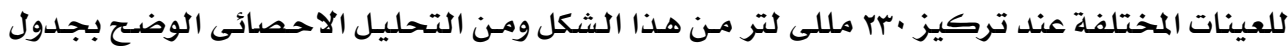

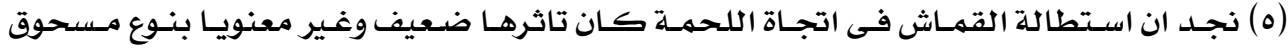
الغسيل

ويشير شكل ( ) ) ان اعلى نسبة استطالة هى التى صاحبت العينـات المغسولة بهسحوق اريال

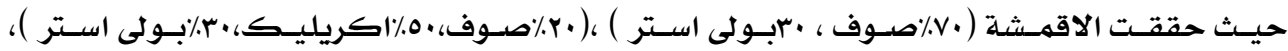

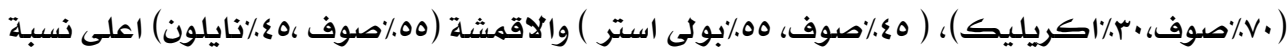

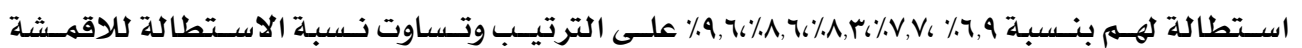

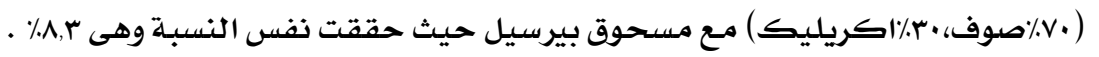

10ـ تأثير نوع مسحوق الفسيل على وزن القماش

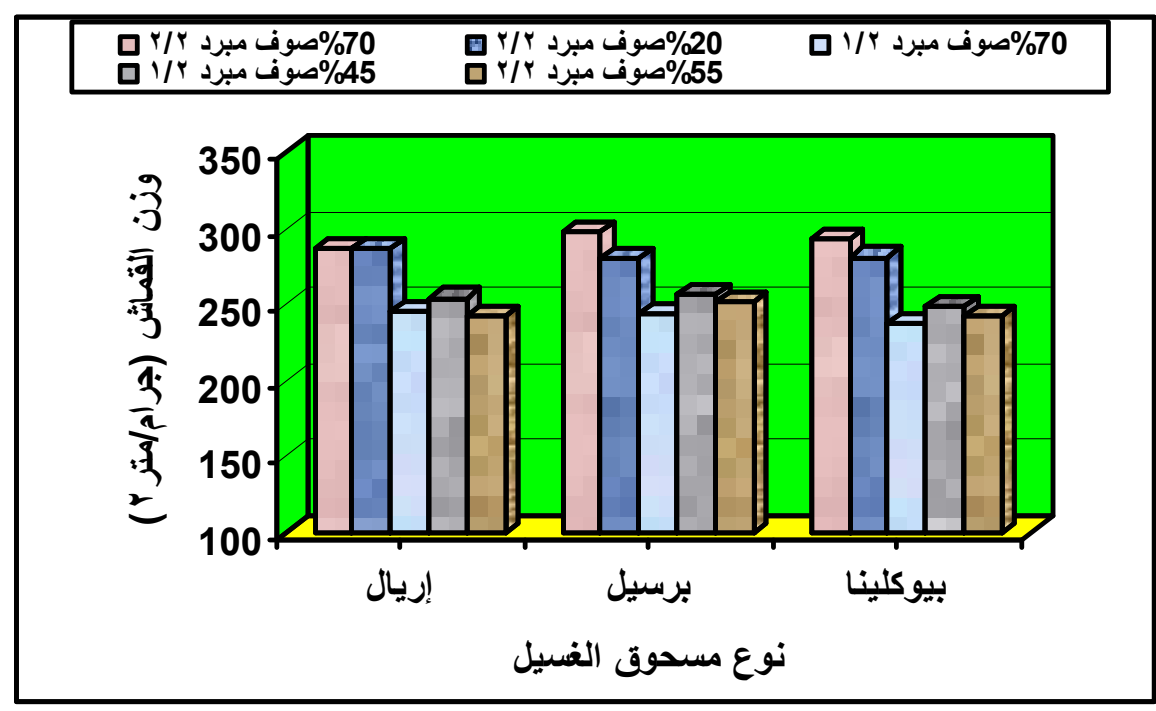

شكل (ه) : العلاقة بين نوع مسحوق الغسيل و وزن القماش للعينات المختلفة عند تركيز · بr مللى لتر 


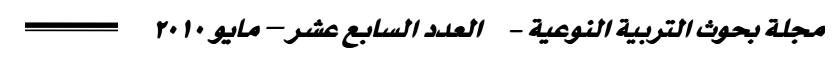

جدول(ج) : تحليل التباين لتأثير نوع مسحوق الغسيل على وزن القماش للعينات المختلفة عند تركيز ·بr مللى لتر

\begin{tabular}{|c|c|c|c|c|c|c|}
\hline قيمـة في & مستوى & قيمسة ف & متوسط المربعات & الحرجـاتة & ملمجموعات المربعات & مصلدر التبـاين \\
\hline \multirow[t]{3}{*}{3.354131} & 0.839655 & 0.175901 & 83.52133 & 2 & 167.0427 & بين المجموعات \\
\hline & & & 474.8213 & 27 & 12820.18 & داخل المجموعات \\
\hline & & & & 29 & 12987.22 & المجموع \\
\hline
\end{tabular}

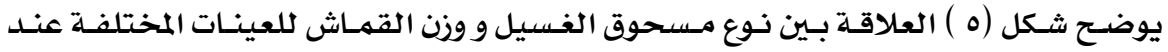

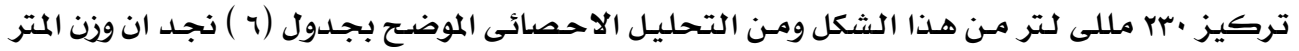

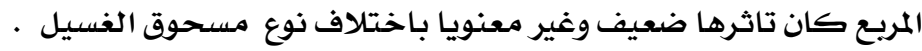

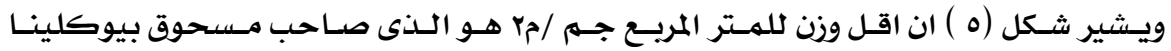

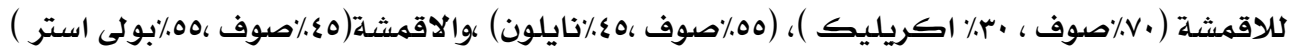

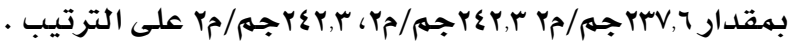

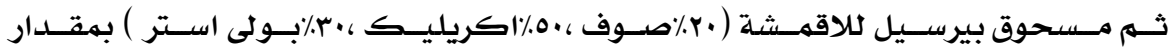

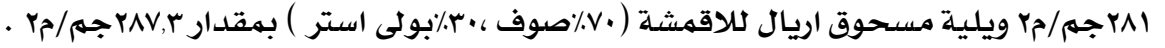

1_ آتأثير نوع مسحوق الفسيل على نسبة انكماش القماش فى اتجاه السلداء

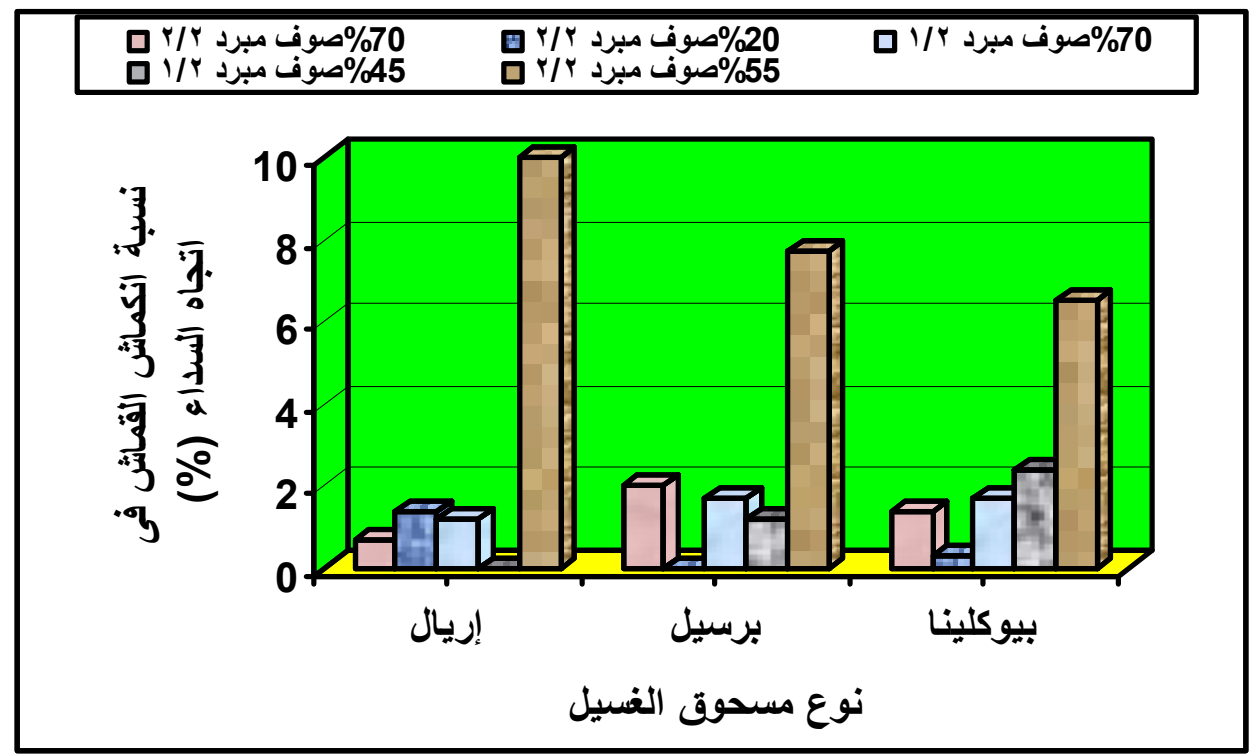

شكل (ج) : العلاقة بين نوع مسحوق الغسيل و نسبة انكماش القماش فى اتجاه السداء

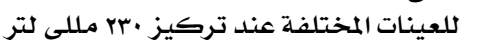


جدول(v) : تحليل التباين لتأثير نوع مسحوق الغسيل على نسبة انكماش القماش فى اتجاه السداء للعينات المختلفة عند تركيز ·rr مللى لتر

\begin{tabular}{|c|c|c|c|c|c|c|}
\hline قيمة ف & مستوى المعنوية & قيمة ف & متوسط المريعات & الحرجية & مجرموع & مصدر التباين \\
\hline \multirow[t]{3}{*}{3.219938} & 0.98275 & 0.017407 & 0.158 & 2 & 0.316 & بين المجموعات \\
\hline & & & 9.076571 & 42 & 381.216 & داخل المجموعات \\
\hline & & & & 44 & 381.532 & المجموع \\
\hline
\end{tabular}

يوضـح شكل (7) العلاقة بين نوع مسحوق الغسيل و نسبة انكماش القماش في اتجـاه السداء

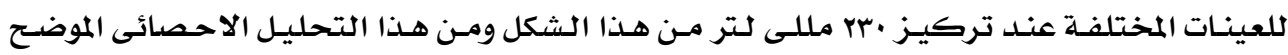

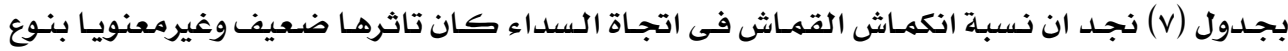
مسحوق الغسيل ماجدول

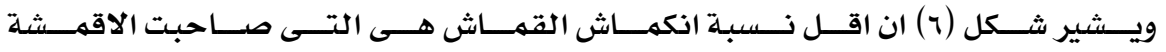

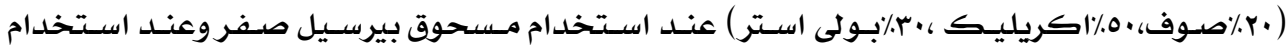

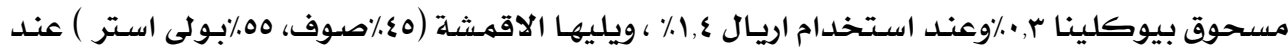

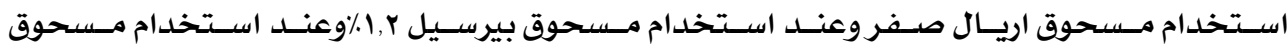

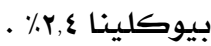

I_r. تأثير نوع مسحوق الفسيل على نسبة انكماش القماش فى اتجاه اللحمة

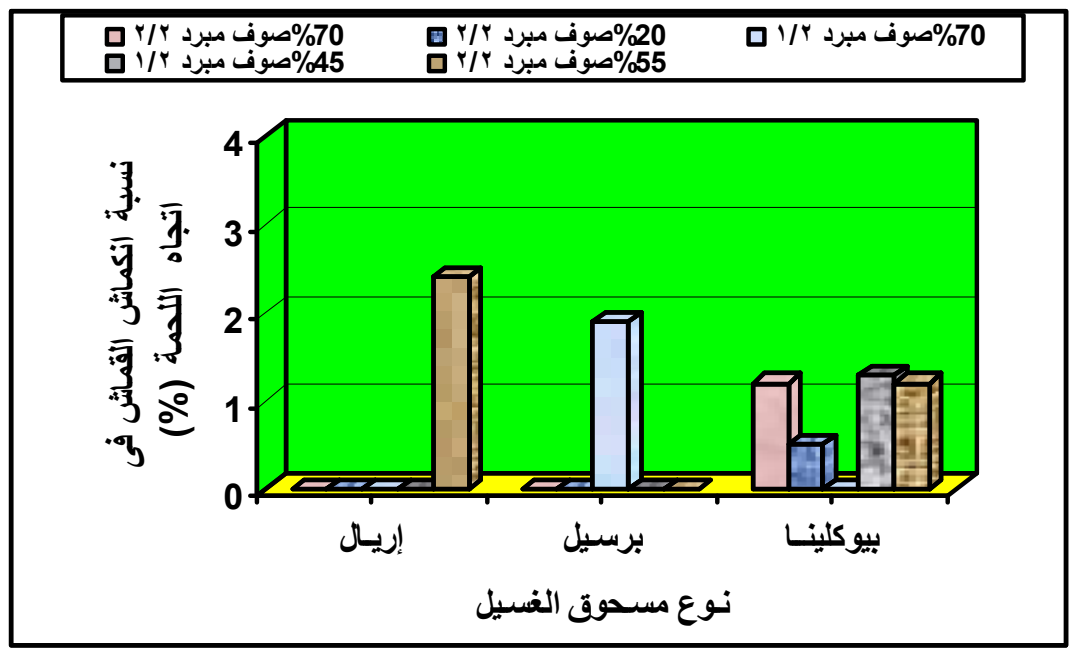

شكل(v) : العلاقة بين نوع مسحوق الغسيل و نسبة انكماش القماش فى اتجاه اللحمة للعينات المختلفة عند تركيز • r مل ملى لتر 


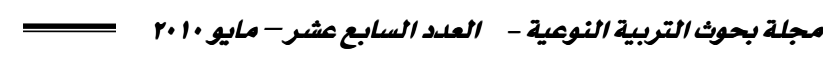

جدول(^) تحليل التباين لتأثير نوع مسحوق الغسيل على نسبة انكماش القماش فى اتجاه اللحمة للعينات المختلفة

\begin{tabular}{|c|c|c|c|c|c|c|}
\hline قيمة ف & مستوى & قلميمة فيسة & متوسط المريعات & الحرجية & مجمموع المربعات & مصلدر التباين \\
\hline \multirow[t]{3}{*}{3.354131} & 0.418741 & 0.899181 & 0.585333 & 2 & 1.170667 & بين المجموعات \\
\hline & & & 0.650963 & 27 & 17.576 & داخل المجموعات \\
\hline & & & & 29 & 18.74667 & المجموع \\
\hline
\end{tabular}

يوضـح شكل (v) العلاقة بين نوع مسحوق الغسيل و نسبة انكماش القماش فى اتجـاه اللحمـة

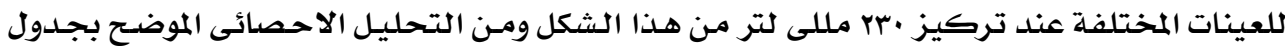

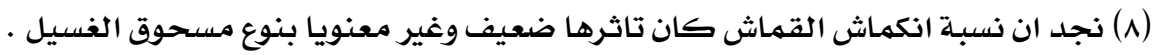

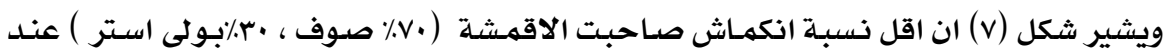

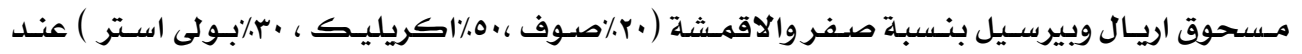

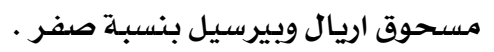

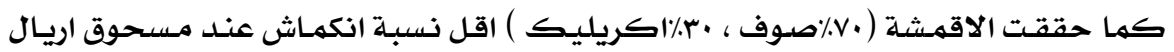

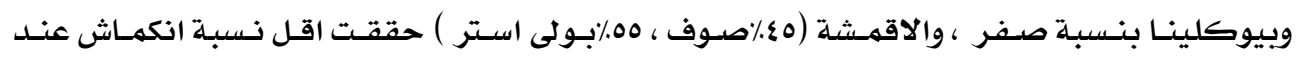

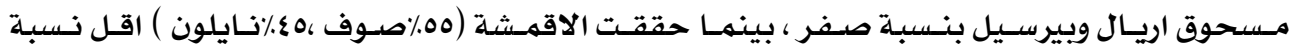

انكماش عند مسحوق بيرسيل .

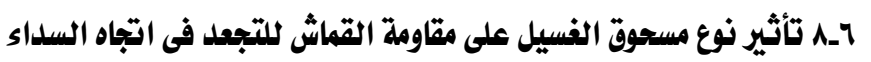

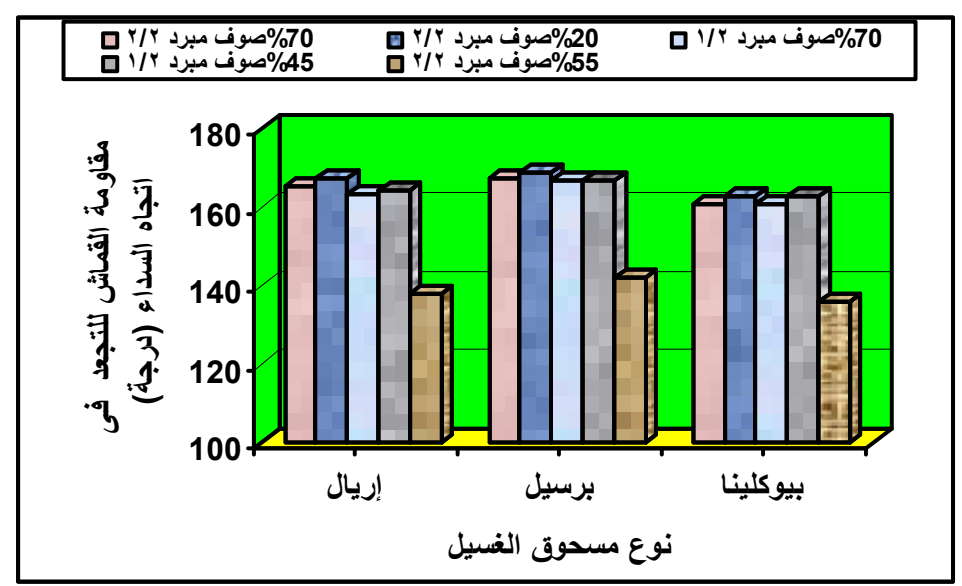

شكل( ^) : العلاقة بين نوع مسحوق الغسيل و مقاومة القماث للتجعد في اتجاه السداء للعينات المختلفة

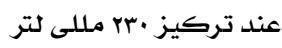


جدول(ه) : تحليل التباين لتأثير نوع مسحوق الغسيل على مقاومـة القماش للتجعد فى اتجاه السداء للعينات المختلفة

\begin{tabular}{|c|c|c|c|c|c|c|}
\hline قالجدولية & مستوية المعنوية & قالمسيمة فية & متوسطات & الحرجية & المربعات & مصدر التباين \\
\hline \multirow[t]{3}{*}{3.354131} & 0.523961 & 0.662061 & 81.79733 & 2 & 163.5947 & بين المجموعات \\
\hline & & & 123.5496 & 27 & 3335.84 & داخل المجموعات \\
\hline & & & & 29 & 3499.435 & المجموع \\
\hline
\end{tabular}

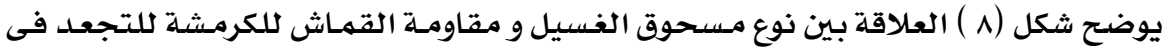

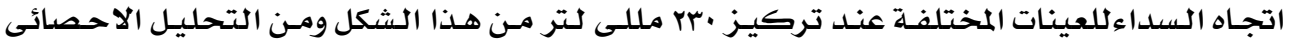

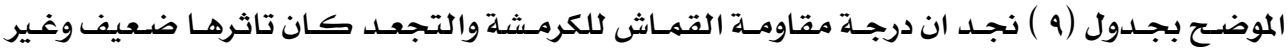
معنويا بنوع مسحوق الغسيل .

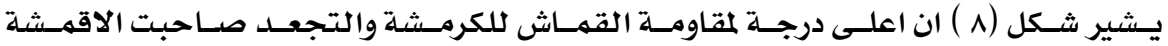

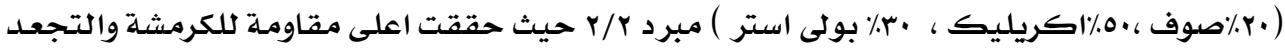

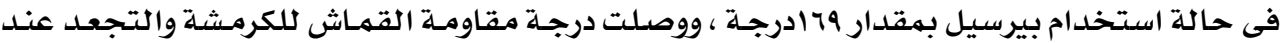

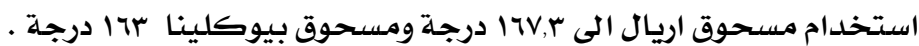

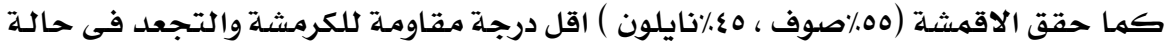

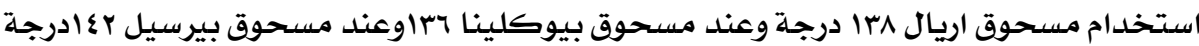

19_9 تأثير نوع مسحوق الفسيل على مقاومة القماش للتجعد في اتجاه اللحمة

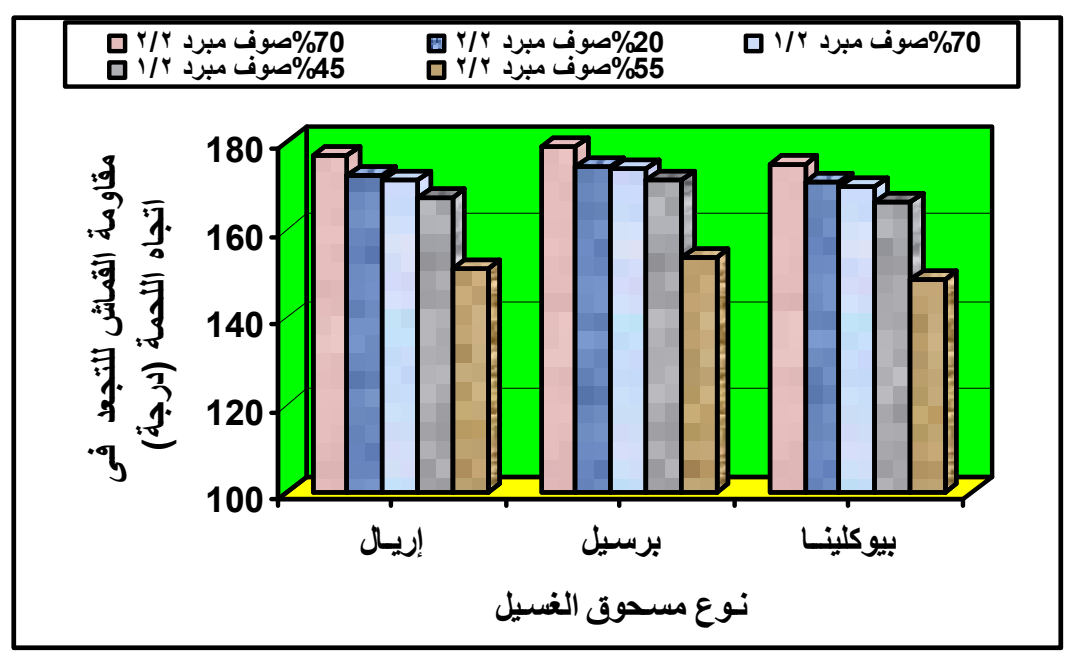

شكل (ه) : العلاقة بين نوع مسحوق الغسيل و مقاومة القماث للتجعد فى اتجاه اللحمهة للعينات المختلفة

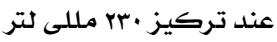




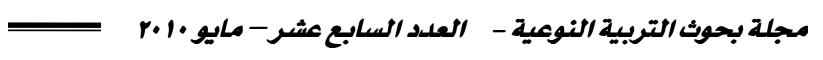

جدول( • ) : تحليل التباين لتأثير نوع مسحوق الغسيل على مقاومة القماش للتجعد في اتجاهاللحمة للعينات المختلفة

\begin{tabular}{|c|c|c|c|c|c|c|}
\hline قيمة ف الجدولية & مستوى المعنوية & قيمة ف & متوسط المريعات & دالحرية & مجمهوع المريعات & مصدر التباين \\
\hline \multirow[t]{3}{*}{3.354131} & 0.600321 & 0.520058 & 46.30533 & 2 & 92.61067 & بين المجموعات \\
\hline & & & 89.03881 & 27 & 2404.048 & داخل المجموعات \\
\hline & & & & 29 & 2496.659 & المجموع \\
\hline
\end{tabular}

يوضـح شكل (ه) العلاقة بين نوع مسحوق الغسيل ودرجـة مقاومة القماش للكرمشـة للتجعـد

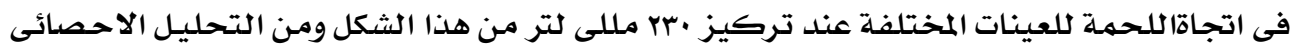

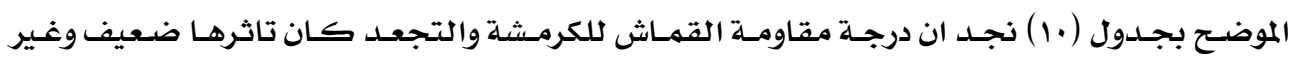

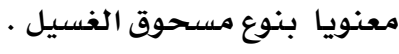

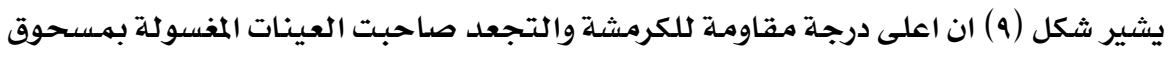

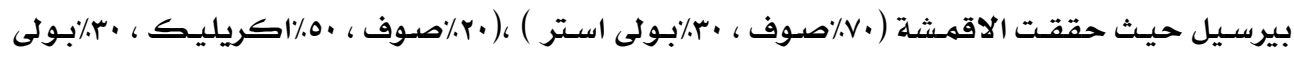

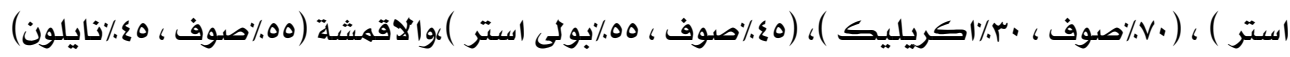

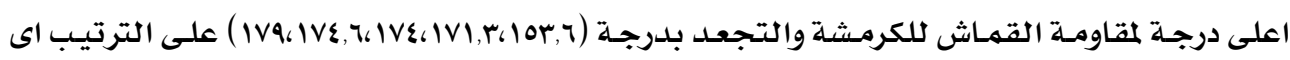

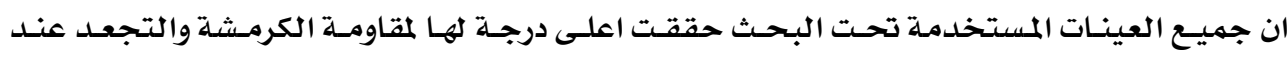

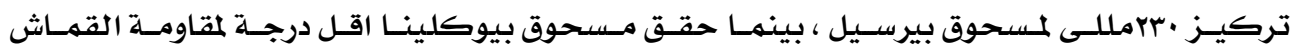

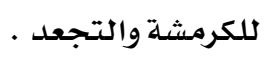

1.-1 تأثير نوع مسحوق الفسيل على مقاومة القماش للتوبير

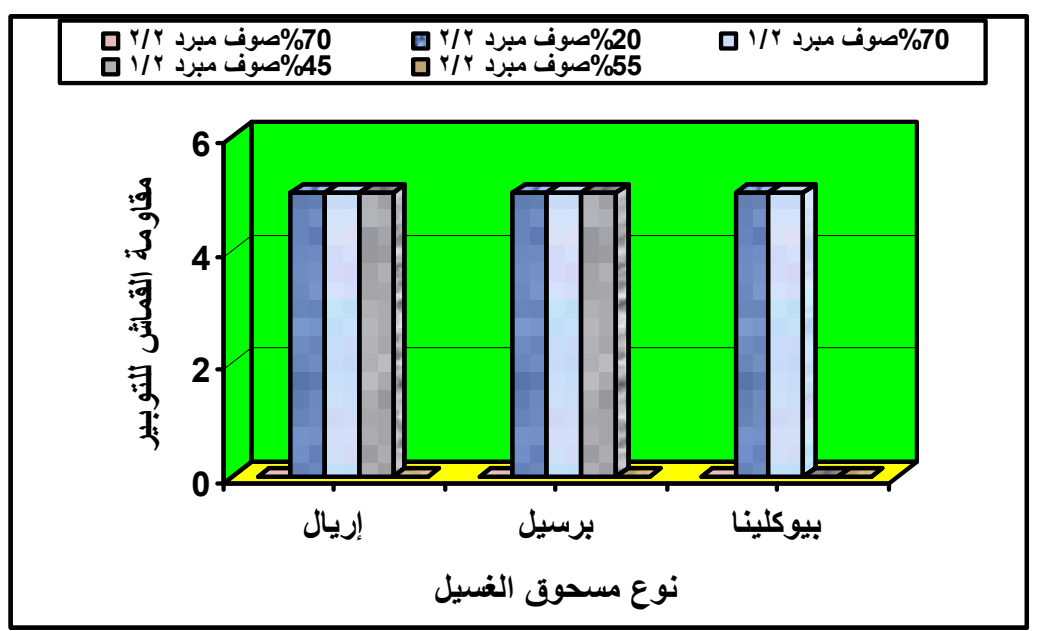

شكل( • ) : العلاقة بين نوع مسحوق الغسيل و مقاومة القماش للتوبير للعينات المختلفة عند تركيز ·r مللى لتر 
جدول(1) : تحليل التباين لتأثير نوع مسحوق الغسيل على مقاقمة القماش للتوبير للعينات المختلفة

\begin{tabular}{|c|c|c|c|c|c|c|}
\hline قالجدمة فية & مستوى & قلميمسة فيس & متوسط المربعات & درجات & المربعات & مصدر التباين \\
\hline \multirow[t]{3}{*}{3.354131} & 0.512037 & 0.5 & 3.333333 & 2 & 6.666667 & بين المجموعات \\
\hline & & & 6.666667 & 27 & 180 & داخل المجمهوعات \\
\hline & & & & 29 & 186.6667 & المجموع \\
\hline
\end{tabular}

يوضـح شـكل ( م ) العلاقـة بــين نـوع مسسحوق الغسسيل و مقاومسة القهــاش للتوبير للعينـات

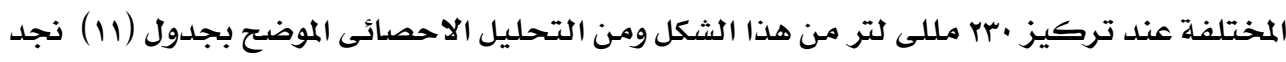

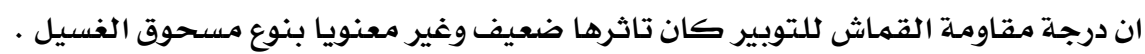

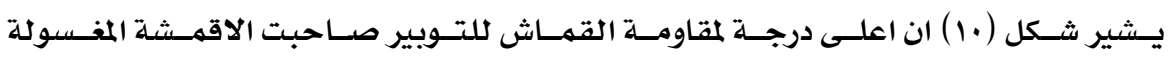

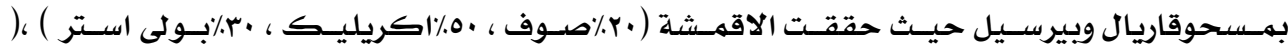

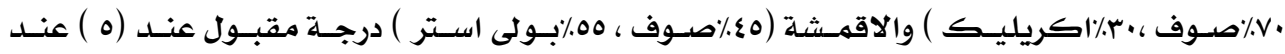

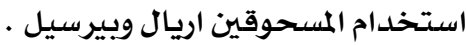

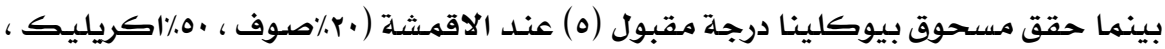

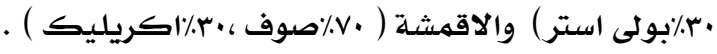

11. 11 تأثير نوع مسحوق الغسيل على نعومة وملسس القماش

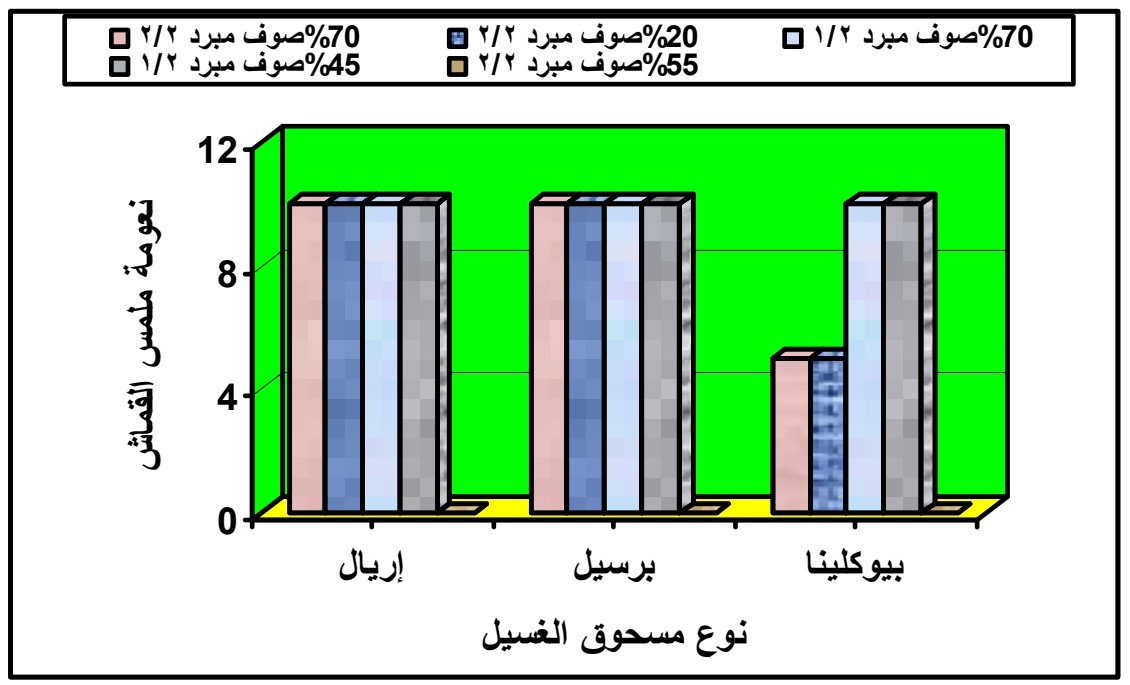

شكل (1) ) : العلاقة بين نوع مسحوق الغسيل و نعومة ملمس القماش للعينات المختلفة عند تركيز ·r مللى لتر 


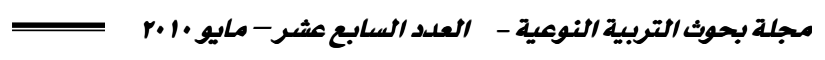

جدول(r ا ) : تحليل التباين لتأثير نوع مسحوق الغسيل على نعومة القماش للعينات المختلفة عند تركيز ·r مللى لتر

\begin{tabular}{|c|c|c|c|c|c|c|}
\hline قيمة فلية & مستوية المعنوية & قيمة في المحسوبة & متوسط المريعات & درجات & مرجموع المربعات & مصدر التباين \\
\hline \multirow[t]{3}{*}{3.354131} & 0.467309 & 0.782609 & 13.33333 & 2 & 26.66667 & بين المجموعات \\
\hline & & & 17.03704 & 27 & 460 & داخل المجموعات \\
\hline & & & & 29 & 486.6667 & المجموع \\
\hline
\end{tabular}

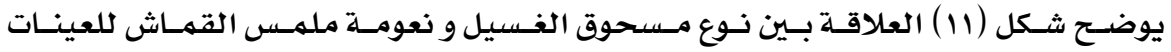

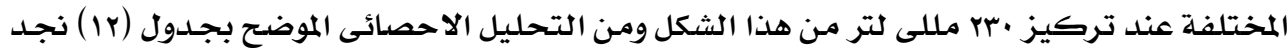
ان نعومة وملمس القماث كان تاثرها ضعيف وغير معنويا بنوع مسحوق الغسيل.

يشير شكل (11) ان اعلى درجة لنعومـة وملمس القماش صـاحبت العينـات المغسولة بهسحوق

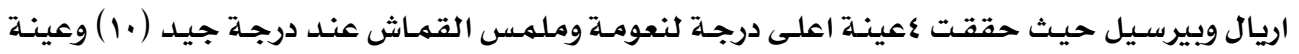

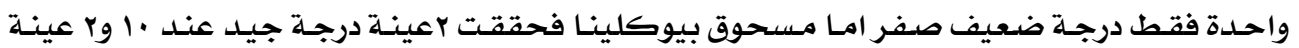

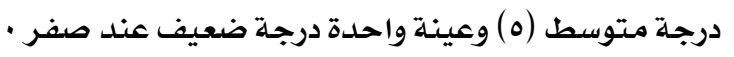

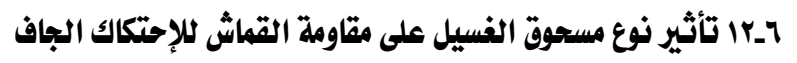

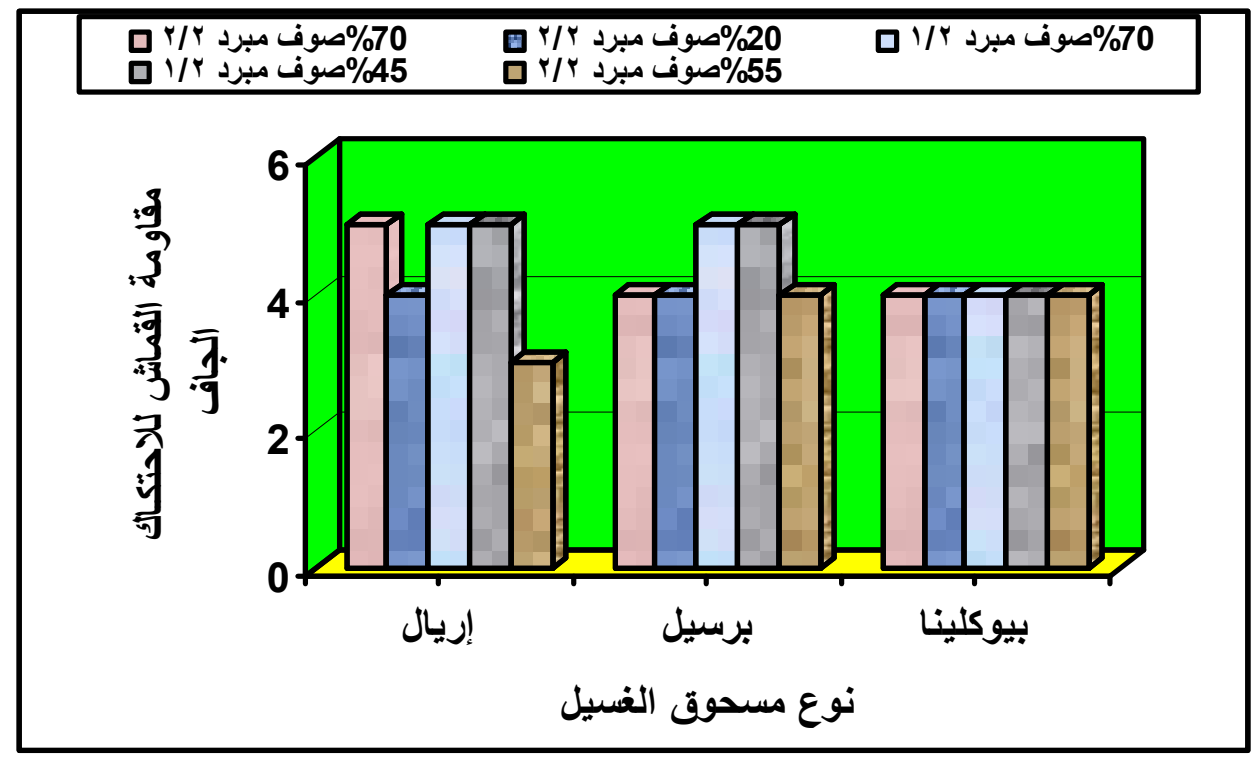

شكل (r ) : العلاقة بين نوع مسحوق الغسيل و مقاومة القماش للاحتكاك الجاف للعينات المختلفة عند تركيز ·rr مللى لتر 
جدول(rا ) : تحليل التباين لتأثير نوع مسحوق الغسيل على مقاومة القماث للاحتكاك الجاف للعينات المختلفة عند

تركيز · بr مللى لتر

\begin{tabular}{|c|c|c|c|c|c|c|}
\hline قالجدولية & مستوى المعنوية & قلمحسمة ف & متوسط المربعات & درجات & مجمبوع المربعات & مصدر التباين \\
\hline \multirow[t]{3}{*}{.354131} & 0.21341 & 1.636364 & 0.533333 & 2 & 1.066667 & بين المجموعات \\
\hline & & & 0.325926 & 27 & 8.8 & داخل المجموعات \\
\hline & & & & 29 & 9.866667 & المجموع \\
\hline
\end{tabular}

يوضـح شـكل (Y ) العلاقـة بـين نـوع مسسحوق الغسيل و مقاومسة القمـاش للاحتكـاك الجـاف للعينات المختلفة عند تركيز •rr مللى لتر .

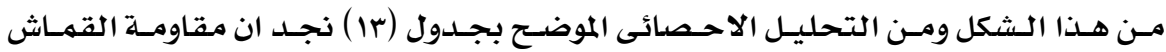
للاحتكاك الجاف كان تاثرها ضعيف وغير معنويا بنوع مسحوق الغسيل .

يشير شكل (r ا ) ان اعلى مقاومـة للاحتكاك الجاف صاحبت العينات المغسولة بمسحوق اريال

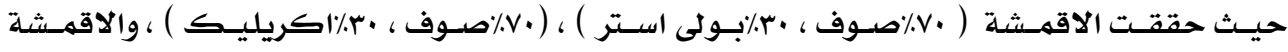

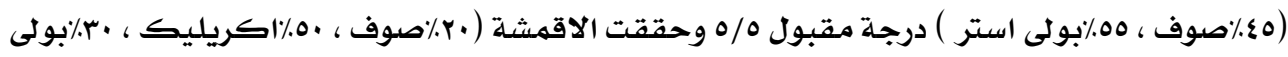

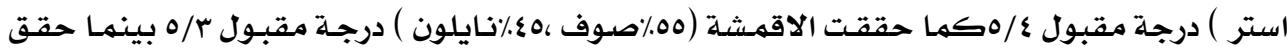
مسحوق بيوكلينا اقل درجهة لمقاومـة القماش للاحتكاك الجاف فحققت جميع العينـات درجـة مقبـول

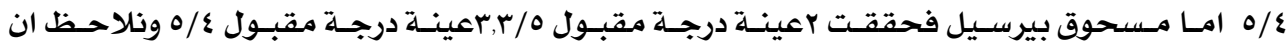

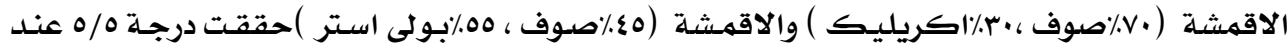
مسحوق اريال وبيرسيل 


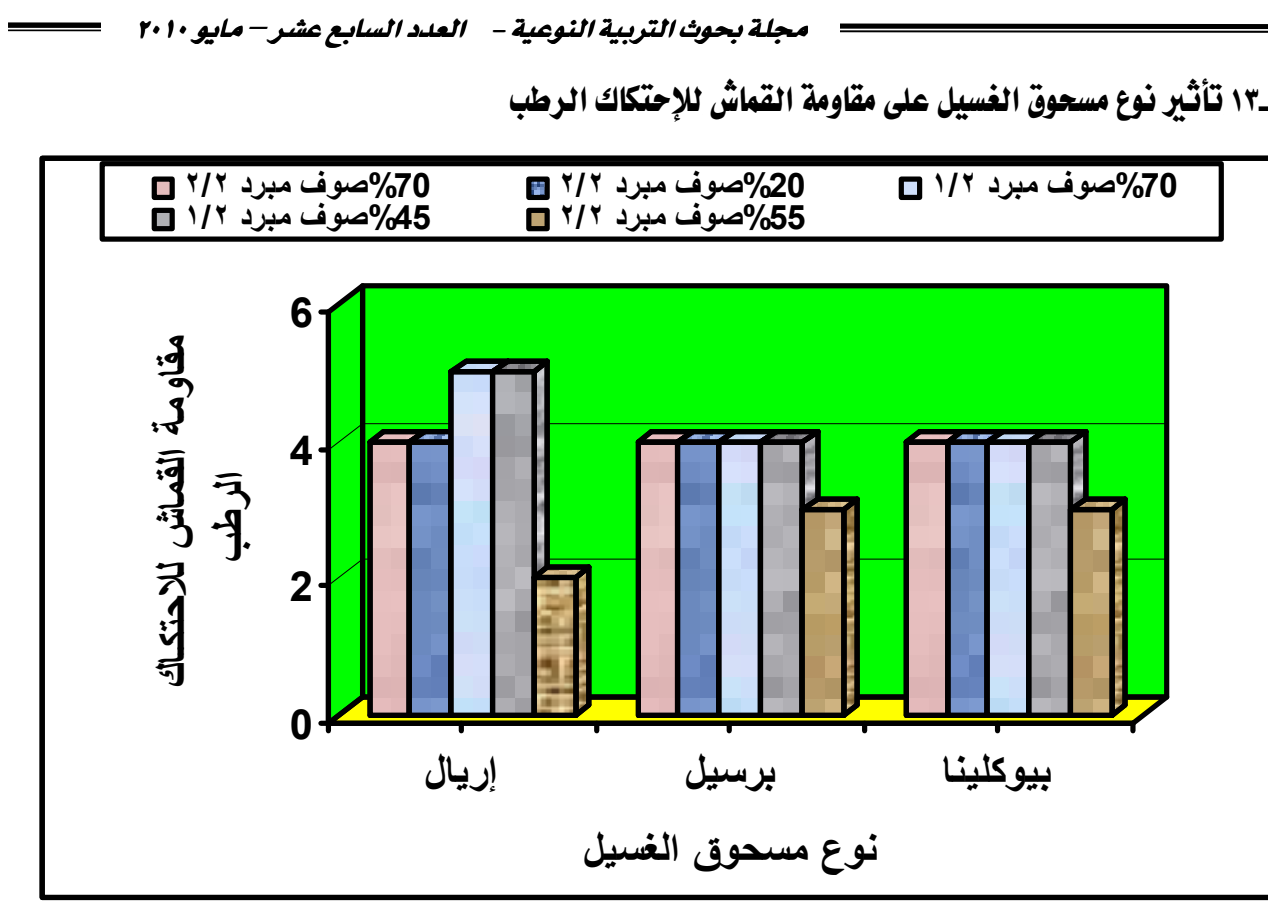

شكل (rا) : العلاقة بين نوع مسحوق الغسيل و مقاومة القماش للاحتكالك الرطب للعينات المختلفة

$$
\text { عند تركيز ·r مب مللى لتر }
$$

جدول(ع) : : تحليل التباين لتأثير نوع مسحوق الغسيل على مقاومة القماش للاحتكاك الرطب للعينات المختلفة

\begin{tabular}{|c|c|c|c|c|c|c|}
\hline قيمة ف الجدولية & مستوى المعنوية & قلمحسمة ف & متوسط المربعات & درجات & مجرموع المريعات & مصدر التباين \\
\hline \multirow[t]{3}{*}{3.354131} & 0.790738 & 0.236842 & 0.133333 & 2 & 0.266667 & بين المجموعات \\
\hline & & & 0.562963 & 27 & 15.2 & داخل المجموعات \\
\hline & & & & 29 & 15.46667 & المجموع \\
\hline
\end{tabular}

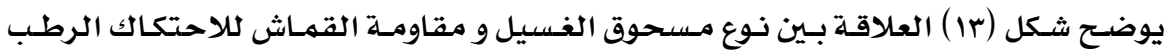

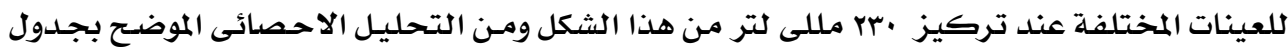

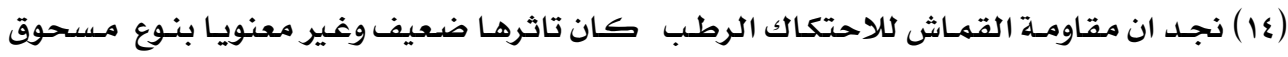

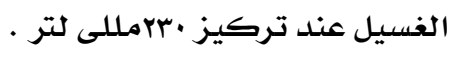

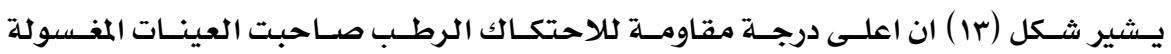

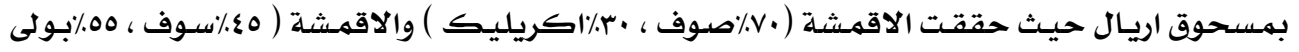




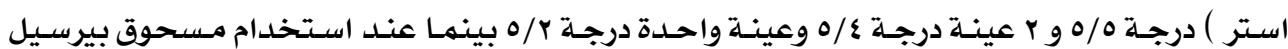

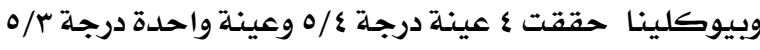

Yـ تقيييم الجودة الكلية للاقفشة الصوفية المخلوطة V_ا تقييم الجودة الكلية للاقشة الصوفية المخلوطة المستخدمة تحت البحث لجميع عوامل الدراسة المختلفة عنـــ

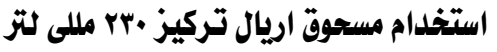

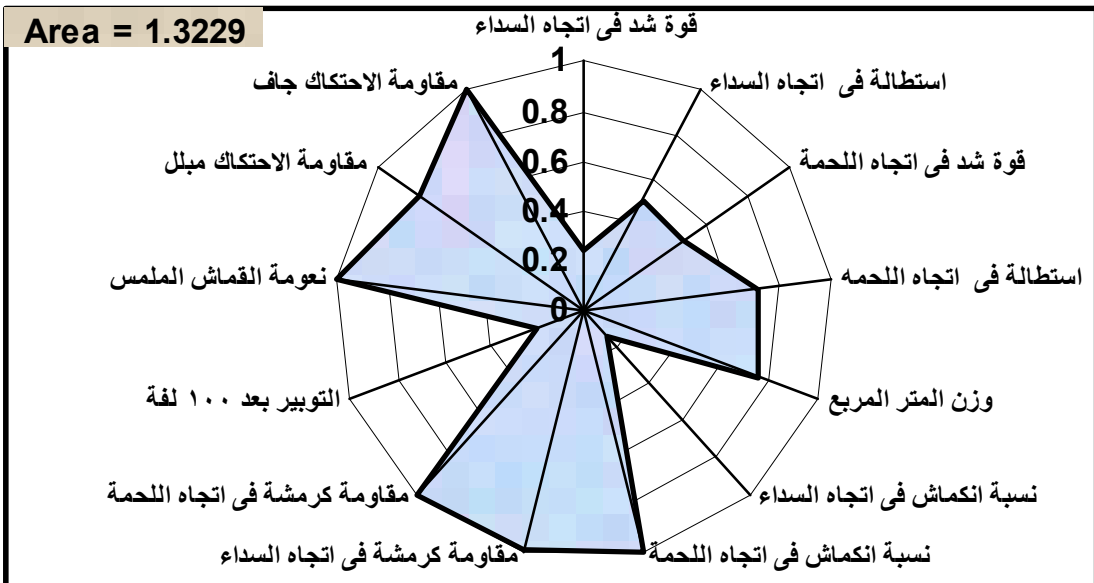

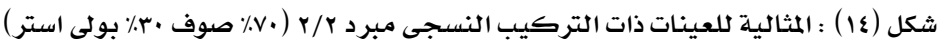
عند تركيز ·rr مللى لتر لمسحوق الغسيل أريال

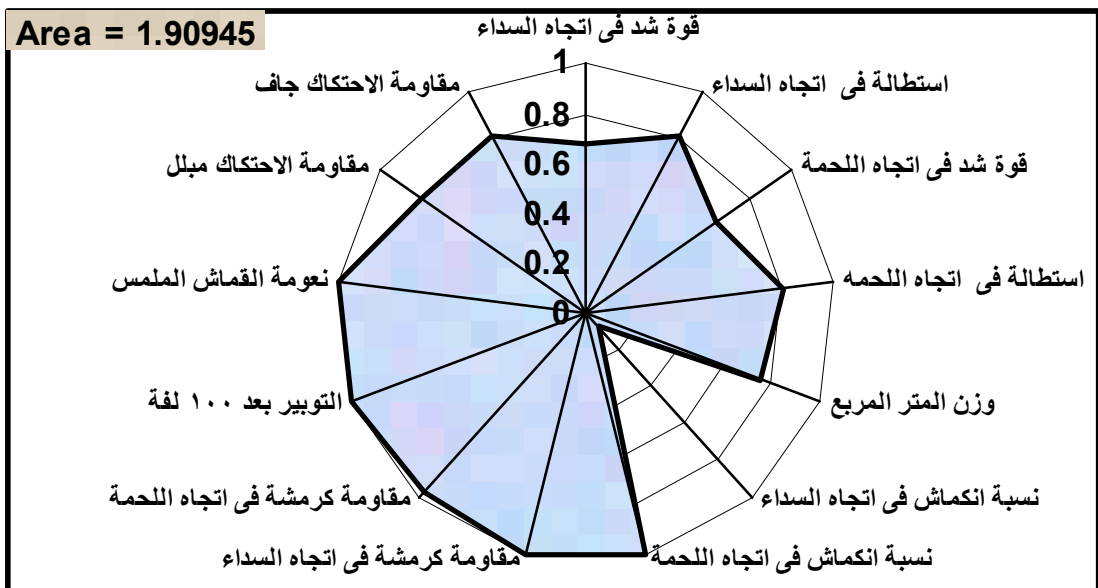

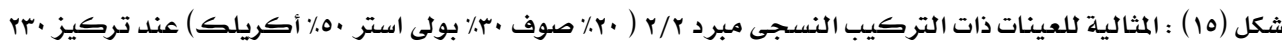
مللى لتر لمسحوق الغسيل أريال 


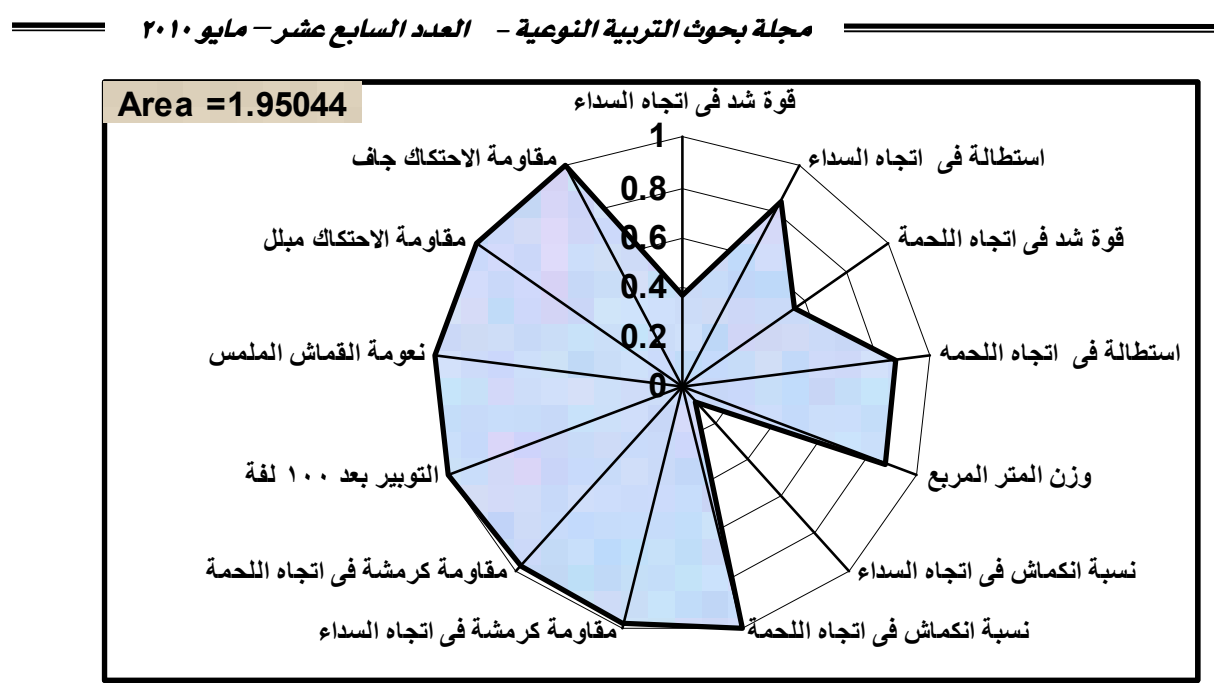

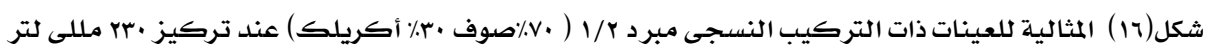
لمسحوق الغسيل أريال

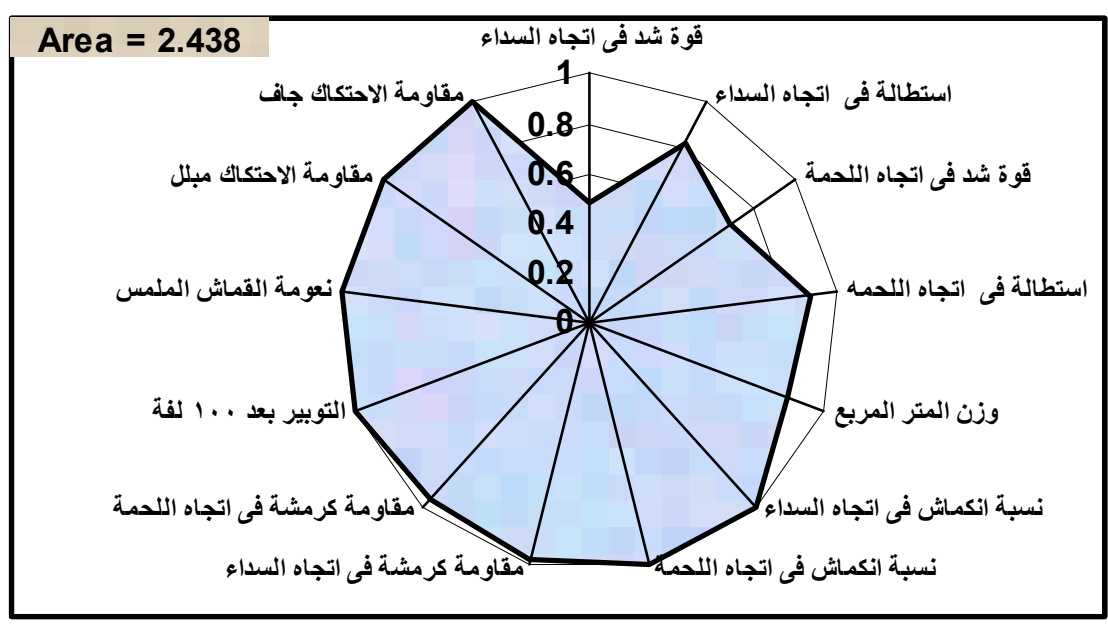

شكل (IV) : المثالية للعينات ذات التركيب النسجى مبرد ب/ ا ( ع ٪ صوف 00٪ بولى استر ) عند تركيز ·r مللى لتر لمسحوق الغسيل أريال 


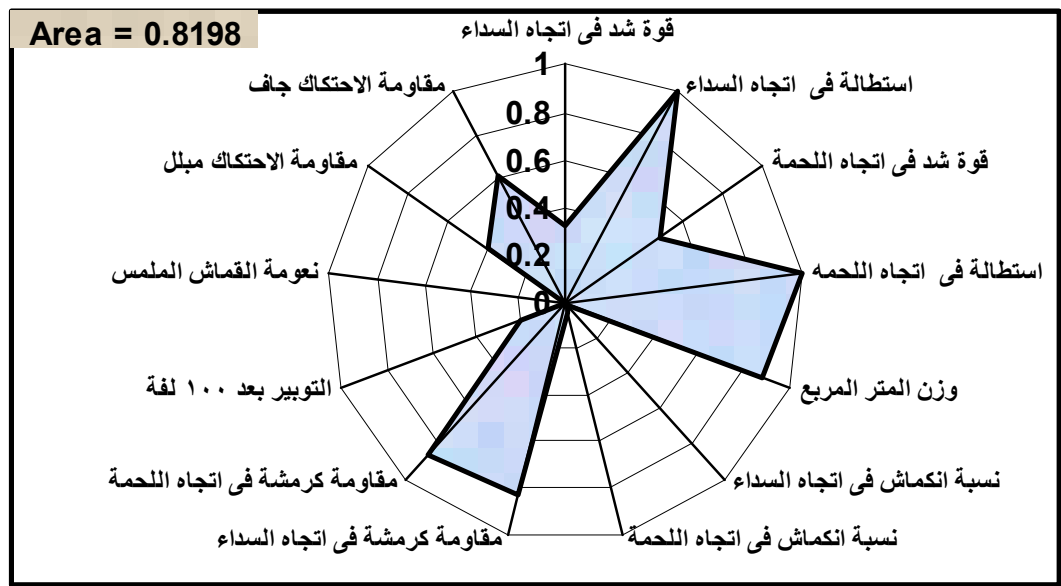

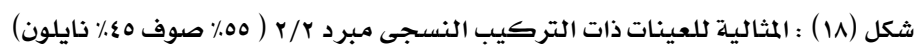
عند تركيز ·r ملم ملى لتر لمسحوق الغسيل أريال

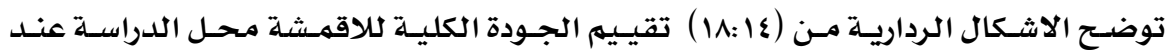

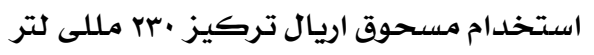

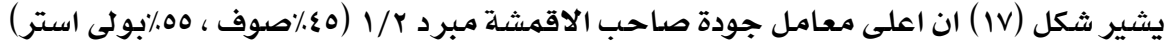

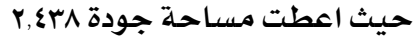

Y_r تقيييم الجودة الكلية للاقمشة الصوفية المخلوطة المستخدمة تحت البحث لجميع عوامل الدراسة المختلفة عند استخدام مسحوق بيرسيل تركيز • بrمللى لتز

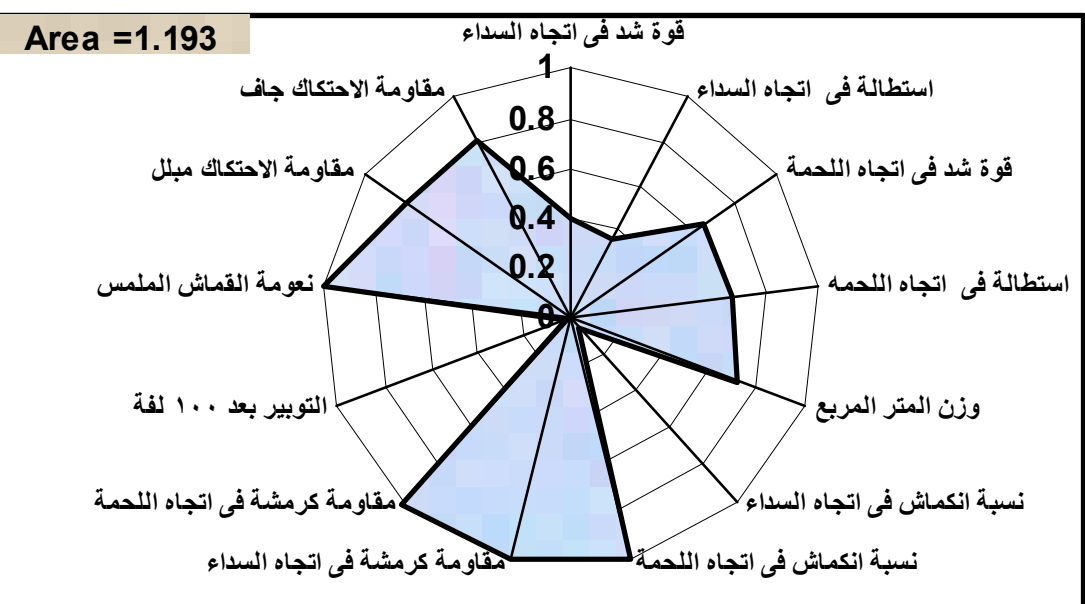

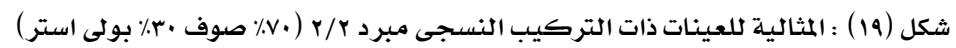
عند تركيز •rr مللى لتر لمسحوق الغسيل برسيل 


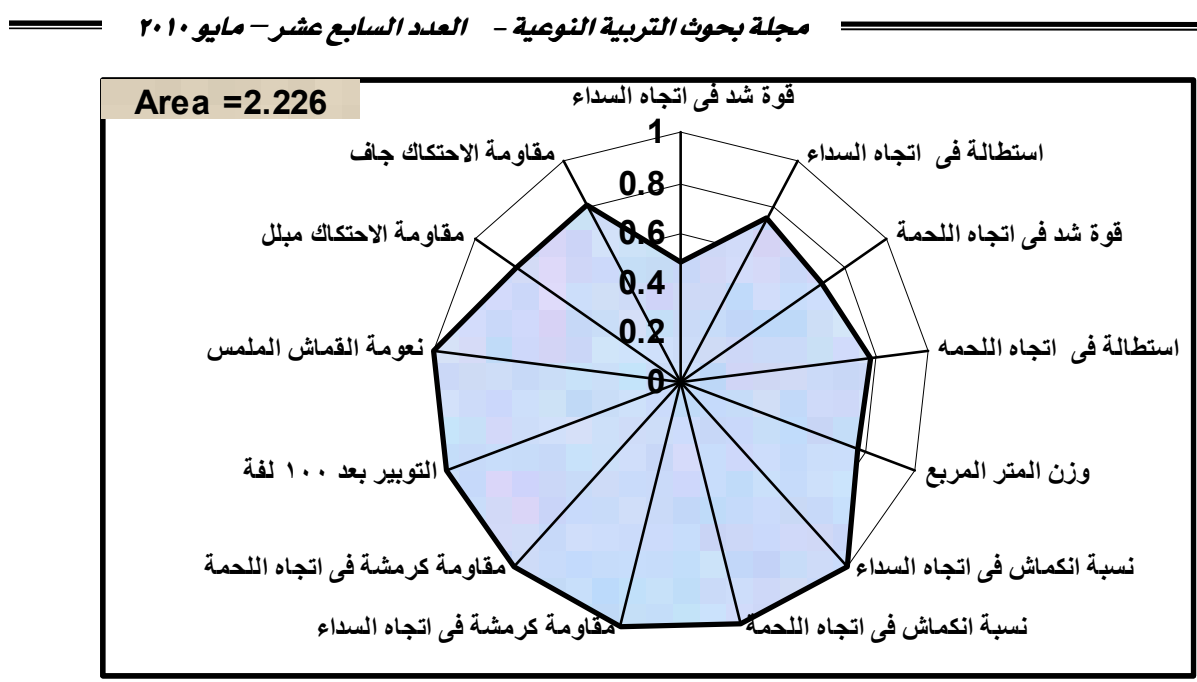

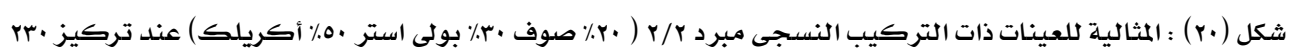
مللى لتر لمسحوق الغسيل برسيل

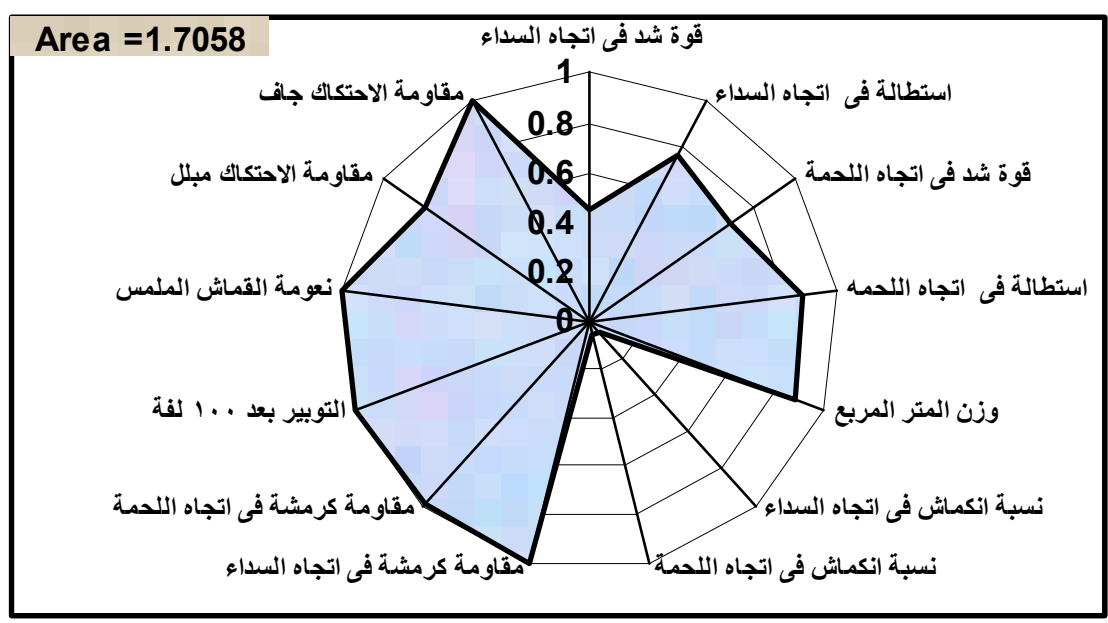

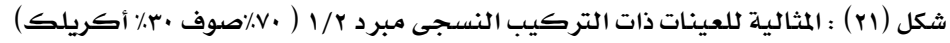
عند تركيز ·rr مللى لتر لمسحوق الغسيل برسيل 


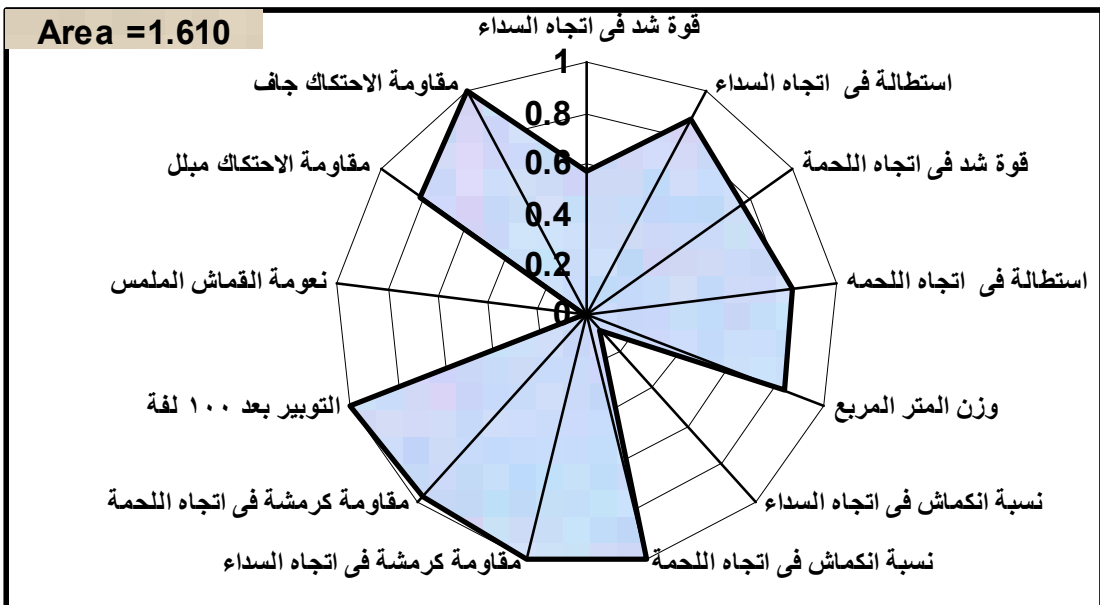

شكل (rr) : المثالية للعينات ذات التركيب النسجى مبرد r/ ا ( 0؟٪ صوف 00٪ بولى استر) عند تركيز •rr مللى لتر لمسحوق الغسيل برسيل

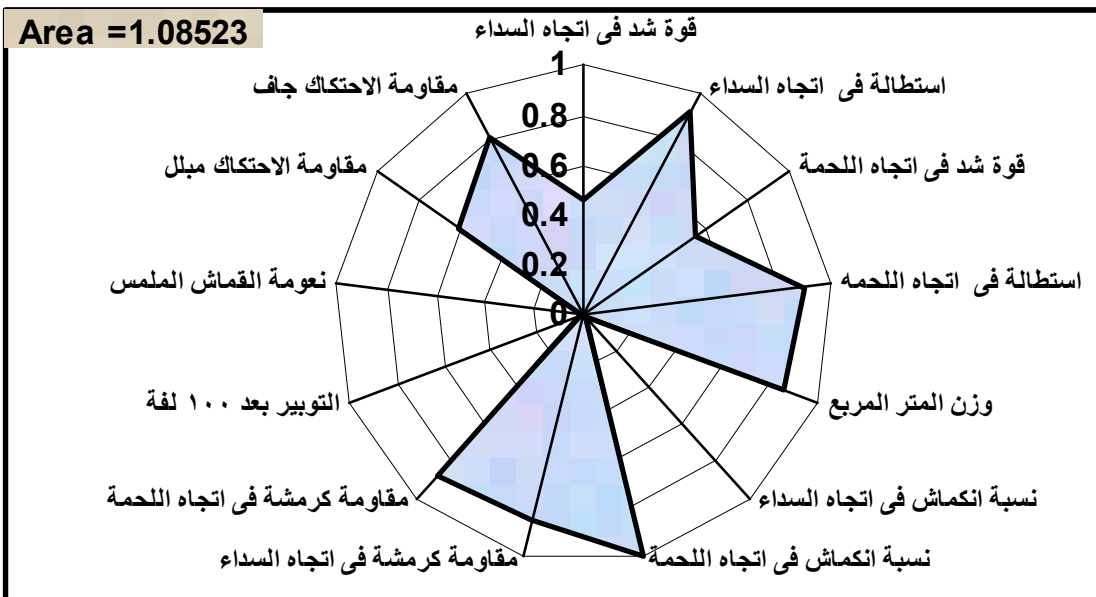

شكل (rr) : المثالية للعينات ذات التركيب النسجى مبرد ب/r ( 00\% صوف 0؟٪ نايلون) عند تركيز · rr مللى لتر لمسحوق الغسيل برسيل

توضـح الاثـكال مـن (19 :rr ) تقيـيم الجـودة الكليـة للاقهـشة محسل الدراسـة عنـد اسـتخدام مسحوق بيرسيل تركيز ·سومللى لتر

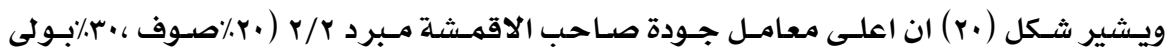

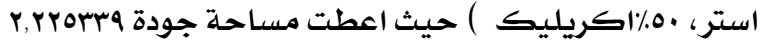




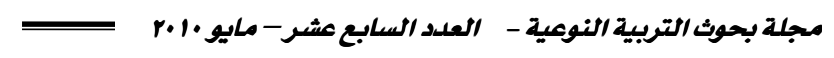

r_Y تقيييم الجودة الكلية للاقمشة الصوفية المخلوطة المستخدمة تحت البحث لجميع عوامل الدراسة المختلفة عند

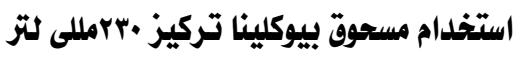

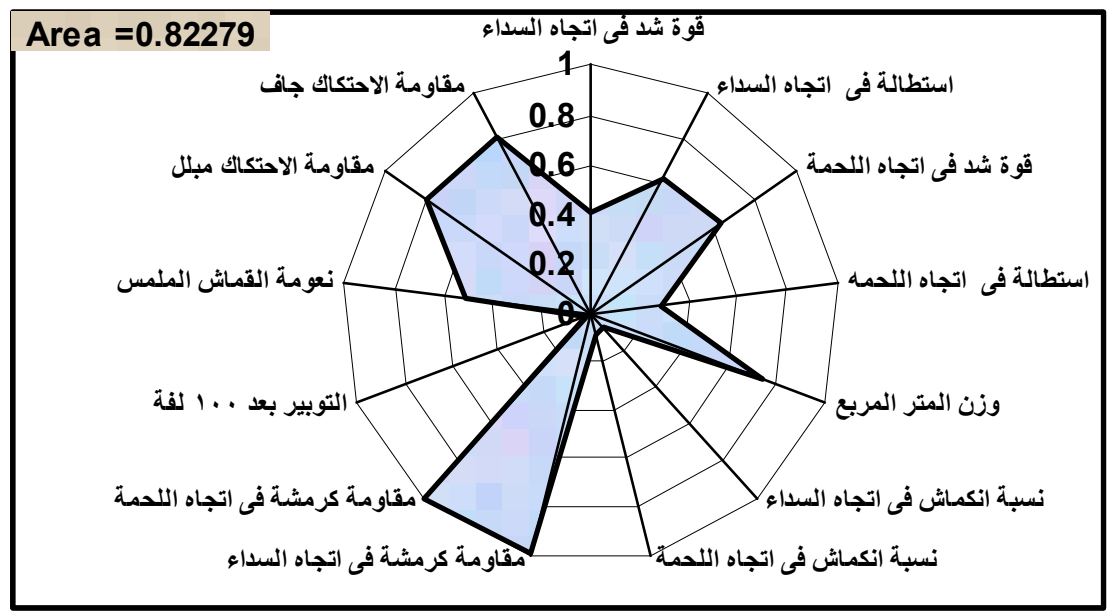

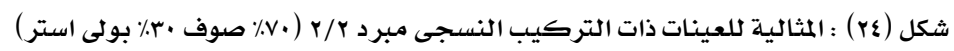
عند تركيز ·rr مللى لتر لمسحوق الغسيل بيوكلينا

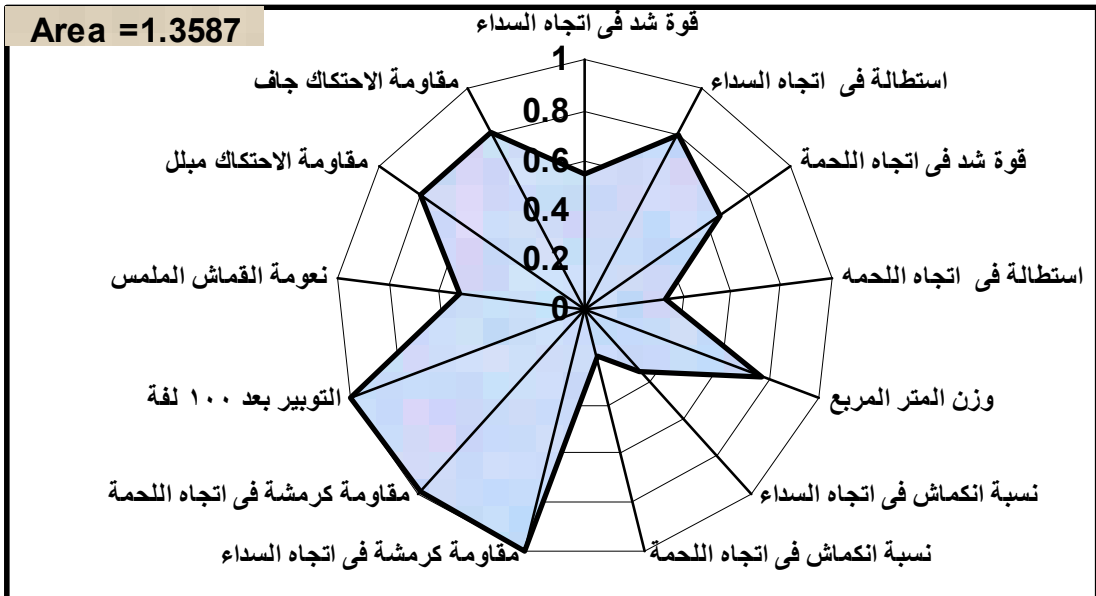

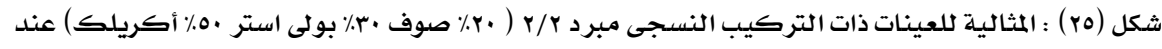
تركيز ·rr مللى لتر لمسحوق الغسيل بيوكلينا 


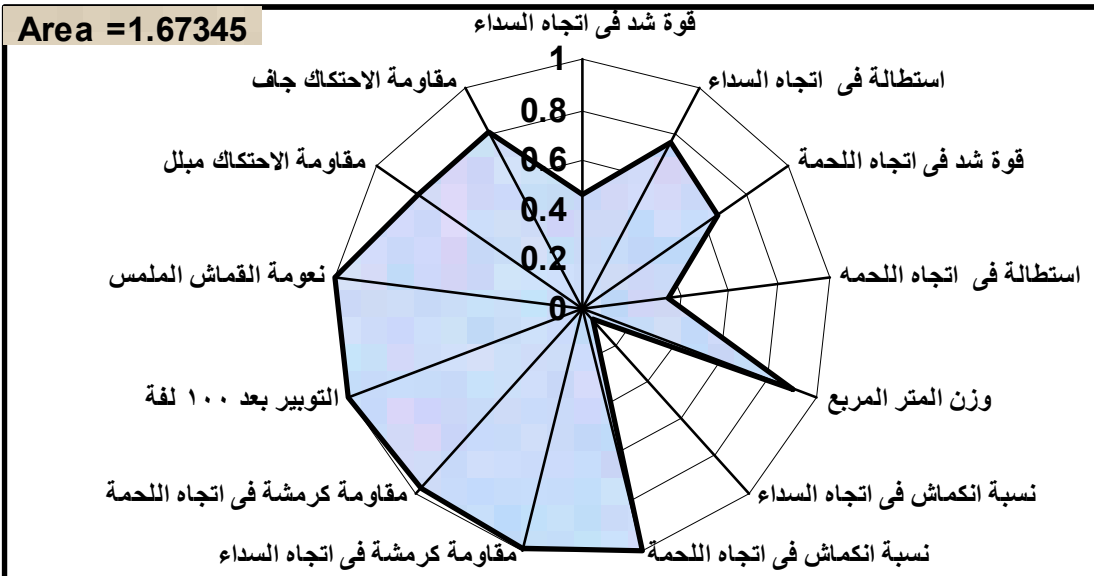

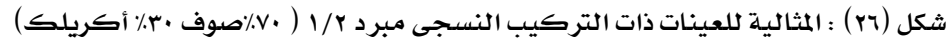
عند تركيز • بr مللى لتر لمسحوق الغسيل بيوكلينا

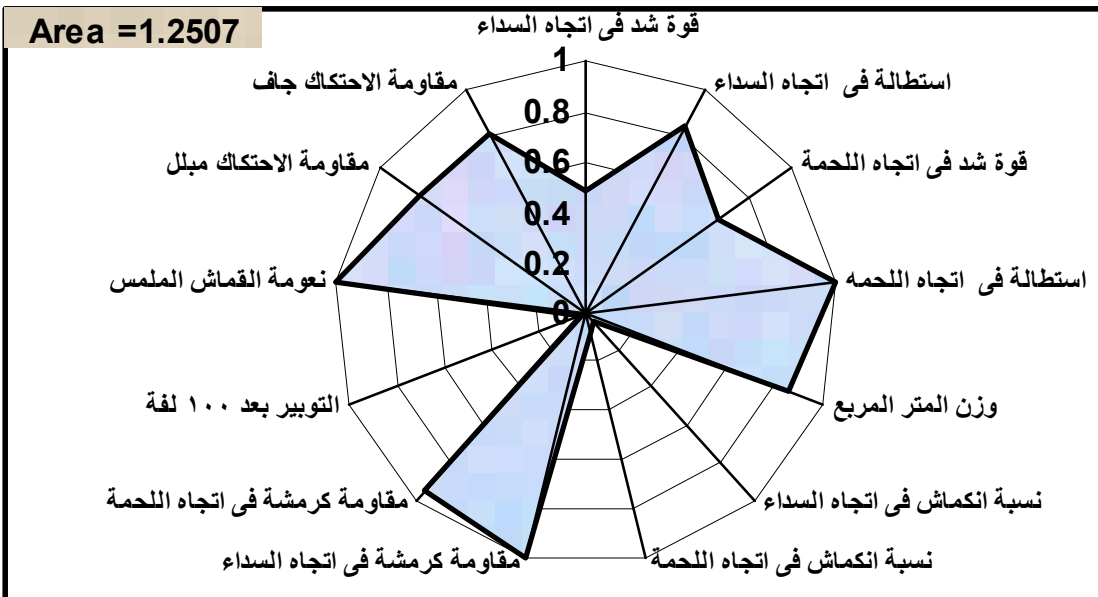

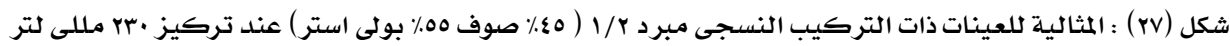
لمسحوق الغسيل بيوكلينا 


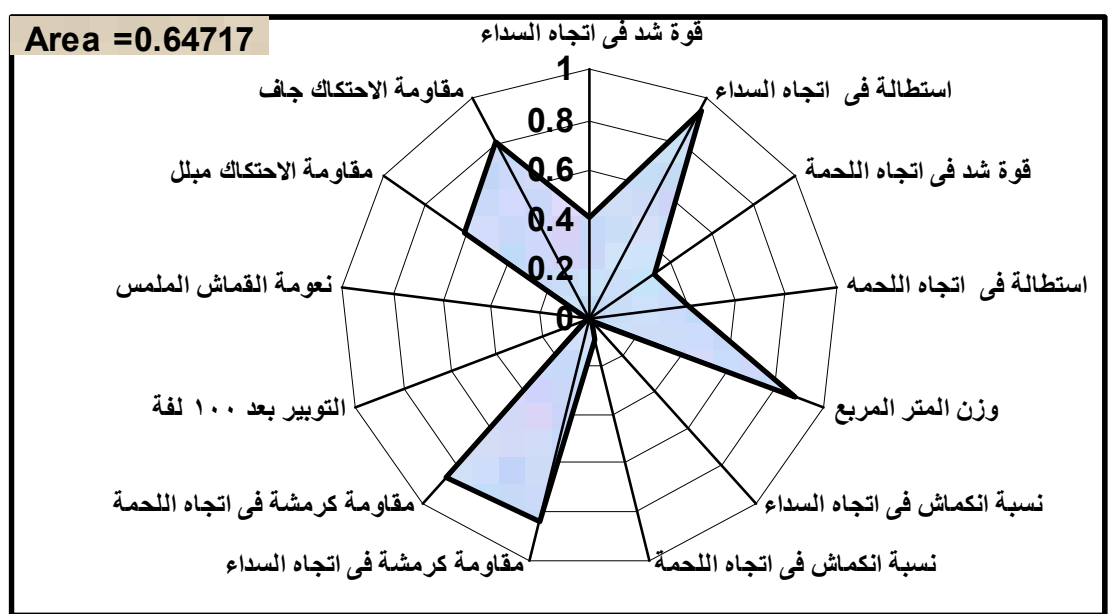

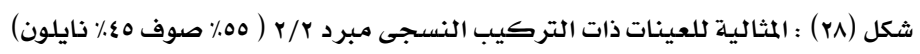
عند تركيز ·rr مللى لتر لمسحوق الغسيل بيوكلينا

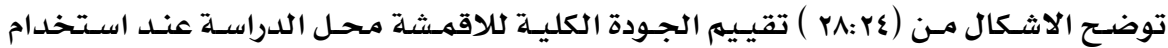
مسحوق بيوكلينا تركيز · س مللى لتر

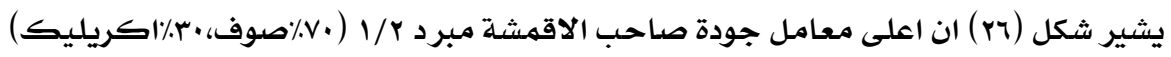

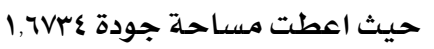

\section{المراجع}

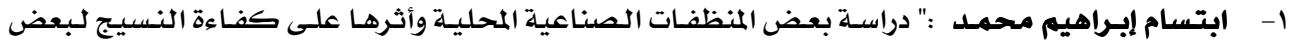

المنتجات الملبسية " ماجستير الاقتصاد المنزلى - كلية الزراعة - جامعة الإسكندرية - 1911 م r- احمد فؤاد النجعاوى :" تكنولوجيا تجهيز الأقمشة الصوفية " منشأة المعـارف - الإسكندرية - الطبعـة

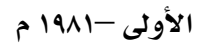

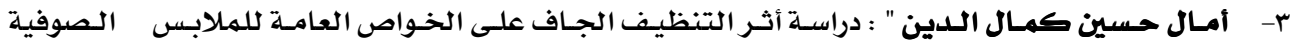
والمخلوطة " - رسالة ماجستير غير منشورة - كلية الاقتصاد المنزلى - جامعة المنوفية - .... Y م

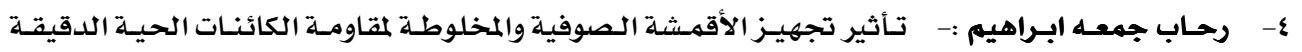
للإيفاء بالغرض الوظيفى للمنتج النهائى - رسالة ماجستير غير منشورة - كلية تربية نوعيـة - جامعة طنطا - ب r..r 


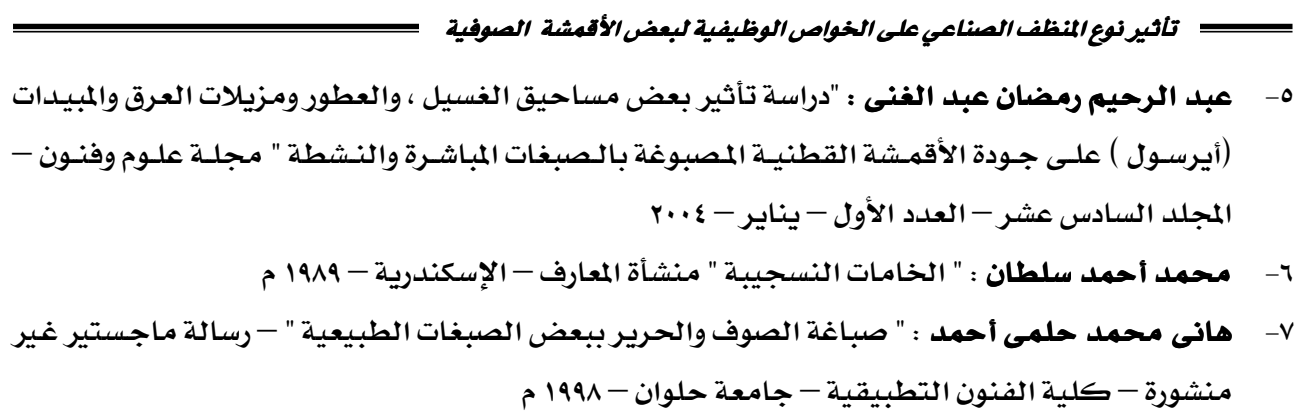

8-Dorthy S.Lyle, Jean Brinkely , " Contemporary clothing" clencoe publishing company, U.S.A .-1990

9- Ehrenkanz , Florence,:" Soap and Chemical specialties " vol. 32, No. (3) P: 41-42-1956

10- Joseph,Marhory,: " Fabric Care and Laundry Products Essentials Of Textiles" Third Edition-1980

11-Parker ,S.P.”Synthetic Detergent” .Detergent Chemistry .Vol (10). NO (4) . P.90-100-1996

12 - Primentas , Coinopouloy,:'Indirect determination of yarn thickness "Textile conference - Egypt -2002

13- Sittin , Marshall:"Zeolite Builders and other New Materials " Detergent Manufacture, No.128. New Jersey U.S.A.-1979

14 - Textil Res. J . 73 (5) , 407-420 -2003

15 -Toback, B,: " synthetic detergent ." detergent chemistry • vol . 25 .No . 4 . $P:(140$ - 145) -1998

16 - Weglinski , S,A and S.K Obendorf, : "Soil Bution On fabric after Laundering " Textile, Chemist and Clourest vol .17. No. 10:196-1985 